\title{
Estados Unidos e América Hispânica: espelhos para uma jovem República
}

\author{
Flávia Maria Ré \\ “- Que pensais do resultado da doutrina de Monroe? \\ - [...] Deixai-me contar o que ouvi, uma vez, de um pobre \\ homem no interior do Brasil. Perguntei-Ihe qual a oração \\ que costumava rezar e ele disse-mo:
}

- Uma muito simples - e depois, acrescentou:

- Antes usava outra, que era esta: 'Com Deus me deito e com Deus me levanto, sob a guarda do Pai, do Filho e do Espírito Santo'.

- E por que não continuastes a rezá-la? - perguntei. - É bonita.

- Ah, senhor! - replicou ele. - Disseram-me que eu obrigava toda a Santíssima Trindade a ficar acordada toda noite, enquanto eu próprio dormia profundamente.

Pois bem, transplantando-a do sacro para o profano, a invocação da doutrina de Monroe pela América latina recorda-me, por vezes, o escrúpulo tocante deste meu patrício. Todos dormimos profundamente com as portas abertas, enquanto ficas [sic] de vigia toda a noite".

Entrevista do Embaixador Joaquim Nabuco publicada em Chicago Tribune, 10 de julho de 1905.

\footnotetext{
${ }^{1}$ Este artigo é a versão modificada do $2^{\circ}$ capítulo da minha dissertação de Mestrado defendida junto ao Departamento de Ciência Política da USP, sob o auspício da CAPES. Agradeço aos pareceristas da revista pelas valiosas sugestões feitas com base em atenta leitura da primeira versão, cabendo-me, naturalmente, a exclusiva responsabilidade pelo texto final.
} 


\section{Resumo}

Este texto tem como objetivo trabalhar com a reflexão dos intelectuais brasileiros sobre os Estados Unidos e a América Latina no contexto conturbado dos primeiros anos da república brasileira, ainda muito marcada pela instituição monárquica. A escolha dos autores presentes neste artigo, assim como o enquadramento por nós empreendido no interior do trabalho foi intencional no sentido de deixar claro que os brasileiros passaram a olhar com mais atenção os exemplos fornecidos pelo continente depois da Proclamação da República. Porém, a divisão do texto em duas partes busca evidenciar também duas visões conflitantes nesse período em relação ao processo de "americanização republicana". A primeira parte é dedicada às primeiras críticas à política de aproximação com os Estados Unidos, cuja obra de Eduardo Prado, A ilusão americana, seria a marca dessa vertente. Na segunda parte, procuramos mostrar como dois autores, Joaquim Nabuco e Oliveira Lima, ainda fortemente atrelados às concepções monárquicas, iriam buscar o exemplo, tanto institucional quanto civilizacional, na imagem de república fornecida pelos Estados Unidos, ao mesmo tempo em que recusavam o exemplo e a aproximação com os demais países latino-americanos. Nesse sentido, já nos primeiros anos da república, pudemos ver de forma mais explícita em Oliveira Lima as concepções de base racial e civilizacional guiando fortemente sua interpretação. Nesse sentido, se formos capazes de demonstrar que a discussão em torno do Panamericanismo no Brasil e da escolha por uma aproximação com os Estados Unidos tinha um forte viés fincado na questão da raça e da civilização, talvez possamos contribuir para iluminar uma face das relações entre o Brasil e as Américas desenvolvidas sob a política do Pan-americanismo na Primeira República.

\section{Introdução}

Com o advento da República, a política externa brasileira voltou-se para uma deliberada aproximação com os Estados Unidos, país que reconhecera, quase de imediato, o novo regime político do Brasil. Contudo, isso não significou que tivessem sido abandonadas as ligações com a Europa, especialmente com a Grã-Bretanha, marca registrada das nossas relações 
exteriores durante o Império ${ }^{2}$. Porém, nem o processo de "americanização republicana", nem a aproximação com os Estados Unidos eram unanimidades no Brasil no final do século XIX. Parte dos intelectuais da época tinha severas críticas a essa política e aos seus propositores. Em livros, na imprensa e no próprio Congresso, homens públicos discordaram exaltadamente do que consideravam uma abdicação da soberania ou uma armadilha imperialista, no caso das relações com os Estados Unidos. Havia também aqueles que discordavam do que consideravam uma "desastrosa" solidariedade latina entre os países ao sul do continente.

Nesse sentido, dizia Rio Branco no seu ofício de 12 de junho de 1902, que "ela [a Doutrina de Monroe] tem sido até hoje um espantalho para impedir intervenções européias, e nos tem servido de muito em algumas ocasiões" (Apud Lins,1965, p. 249). Euclides da Cunha, por sua vez, refere-se ao nosso recuo espavorido diante do "espantalho do perigo sul-americano" (Cunha, 1995, p. 194). A linguagem fantasmagórica de dois dos maiores personagens da República brasileira reflete a preocupação em torno da Doutrina Monroe e do tema do Pan-americanismo que conviveu paralelamente, no Brasil, nas primeiras décadas republicanas, com 0 debate acerca da superação da Monarquia e da construção da República recém proclamada e da transição do trabalho escravo para o trabalho livre e assalariado.

A partir de meados do século XIX teve início entre os pensadores do continente americano um forte debate em torno da polêmica Doutrina Monroe. Também no Brasil, cada um, ao seu modo, procurava justificar sua posição política; ora condenando-a como expressão do imperialismo ianque; ora defendendo-a como forma de proteção dos países americanos em relação aos perigos externos; ou ainda, como uma forma de integração dos países do continente (Cf. Pereira, 2006, p. 59). Na primeira década republicana, diante do quadro internacional que se apresentava - com os rumos das Repúblicas

\footnotetext{
${ }^{2}$ Com a Proclamação da República em 1889, a diferença de regime não mais existia como elemento de diferenciação e distanciamento entre o Brasil e as Repúblicas hispano-americanas. Entretanto, o Brasil republicano reforçaria assim, uma tendência de aproximação com os Estados Unidos. Como observa Oliveira Lima: "De começo o Império tinha contado muito com a simpatia britânica porque a cisão do Reino Unido favorecia os interesses comerciais ingleses, e da Inglaterra se importou o constitucionalismo como sistema de governo; mas a tendência de aproximação política foi mais pronunciada para o lado da América do Norte. Das repúblicas neo-espanholas distanciavam o Brasil antipatias peninsulares herdadas e transplantadas e prevenções filiadas na sua natureza imperial que parecia pronunciar absorções e emulações". (Oliveira Lima, s. d., p. 469-470).
} 
hispano-americanas e a preponderância no continente dos Estados Unidos muitos pensadores brasileiros foram buscar na América hispânica e ou nos Estados Unidos referências para reforçar suas concepções políticas, fossem elas Monárquicas ou Republicanas.

Cabe lembrar que nesse momento a problemática brasileira passa a existir como parte de um sistema mais abrangente, o das Américas, pois a planta "exótica" do continente havia sido arrancada com a República. O movimento da neocolonização, agora sob o controle norte-americano, a aproximação ideológica com os Estados Unidos, em detrimento de suas antigas relações com a Europa e a experiência de uma instabilidade político-financeira tanto do Brasil, quanto das suas vizinhas repúblicas sul-americanas, impulsionaram as interpretações continentais, a auto-análise, a investigação de seus elementos constitutivos e das diferenças culturais entre os países americanos. Houve, neste período, um evidente fortalecimento de uma consciência americana no Brasil, ainda que o exemplo norte-americano tenha sido aquele que ganhou a adesão efetiva da maioria dos intelectuais ${ }^{3}$.

O contexto internacional, marcado pela corrida imperialista entre os países centrais, também trouxe para a ordem do dia reflexões em torno das representações daqueles países em sua relação com o Brasil. As operações políticas com os Estados Unidos e com o continente americano, ganhando forma através do monroísmo e sob a égide da política pan-americanista, começavam a ganhar importância para os intelectuais do período que principiaram a conferir-Ihes sentido e os rumos que seriam, mais tarde, em linhas gerais, retomados e aprofundados por Rio Branco.

Desse modo, no contexto mais amplo do debate político-intelectual da Primeira República, surgem interpretações concorrentes a respeito das possibilidades de os Estados Unidos, como civilização e ordem institucional, constituírem um modelo nesse campo para o Brasil. Ao mesmo tempo, colocava-se também a questão de saber o quanto de fato o país pertencia, ou poderia pertencer, a uma desejável ou não, unidade continental, incluída aí a América hispânica.

\footnotetext{
${ }^{3}$ Sobre o período em questão, Antonio Candido, expressa que "foi nele que se desenvolveu a reflexão mais sistemática sobre a América Latina, em escritos devidos a homens de elevado porte mental, como Joaquim Nabuco, Sílvio Romero, Eduardo Prado, Oliveira Lima e um menos ilustre mas sem dúvida mais lúcido neste terreno, Manoel Bomfim". (Candido, 1993, p. 132).
} 
O meio intelectual brasileiro do final do Império e começo da República colocou-se no centro desse debate e dos variados embates políticos que 0 tema da americanização republicana suscitou. A discussão e o aparecimento de obras em torno do tema do Pan-americanismo deram-se entre os partidários de vários matizes do novo regime e seus adversários de toda ordem, não apenas monarquistas, mas republicanos, críticos aos rumos referentes à inserção internacional do Brasil, ou já desiludidos ou inconformados com a tibieza e lentidão das mudanças internas do país.

Nesse sentido, Angela Alonso, ao analisar o debate político-intelectual da primeira década republicana, salienta que o golpe republicano de 1889 suscitou manifestos, ensaios, romances, historiografia, memórias e autobiografias que permitiram mapear duas principais movimentações intelectuais nesse período. Enquanto os republicanos escreveram, como era de se esperar, legitimando o novo arcabouço político e a sociedade nova que também se estabelecia, os monarquistas por sua vez, escreveriam louvores ao antigo regime e à sociedade aristocrática que estava desmoronando juntamente com eles $^{4}$.

O combate à tradição imperial ficou acirrado e violento no segundo governo da República. Floriano Peixoto, ao assumir em fins de 1891, centralizou o poder, nomeou jovens militares para o governo dos estados, interveio na economia para conter a crise econômica do Encilhamento, fechou jornais e decretou prisão de opositores. A ação de Floriano na repressão à Revolta da Armada, com o auxílio norte-americano, ajudou a formar a imagem de "consolidador da República" que adquiriu entre seus contemporâneos e na historiografia. A ação de Floriano marca também o aparecimento de uma corrente político-ideológica denominada jacobinismo ${ }^{5}$, que tem como marcas

\footnotetext{
${ }^{4}$ Para Alonso, com a instauração da República, em 1889, o debate político-intelectual brasileiro ganhou nova estruturação, sobrepondo duas clivagens: "A primeira refere-se ao contexto político e aos conflitos, palpáveis e nevrálgicos, acerca do formato e dos mandatários do novo regime. [...] A outra clivagem, menos lembrada, e de visibilidade mais difícil, diz respeito ao contexto social de luta entre os estratos sociais dominantes na monarquia e os estratos ascendentes com o novo regime". (Alonso, 2009, p. 133).

${ }^{5}$ O florianismo ficou próximo a que Vovelle chamou de "jacobinismo transhistórico": "o termo 'jacobino', assim como o conceito de jacobinismo, pertence a este registro excepcional em que uma palavra, escapando de seu limite geográfico e do contexto histórico de seu nascimento, reveste-se de um significado mais geral, que designa, para o bem e para o mal, uma atitude, um comportamento e até uma visão de mundo. [...] o jacobinismo não remete diretamente a um sistema social ideal determinado. Ele é geralmente associado ao sistema de valores nascidos da Revolução Francesa, mas seu conteúdo democrático não é universalmente reconhecido. Ele chega a ser contestado, na medida em que seu conteúdo é ambíguo e discutido (burguês ou popular?). Ao invés de se fechar em um programa preciso, o
} 
centrais o nacionalismo, o anti-monarquismo e o florianismo (Cf.QUEIROZ, 1986). O jacobinismo tinha como base a Primeira República Francesa e consolidava a visão da nação em armas contra a ameaça monarquista - toda e qualquer oposição ao grande líder passa a ser vista como uma ameaça às próprias instituições frágeis da nascente república, que deveria ser protegida acima de tudo.

Os monarquistas, que não aderiram em princípio à República, bifurcaram-se em "monarquistas de espada", como Saldanha da Gama, um dos líderes da Revolta da Armada, que acabou por pegar em armas para defender o antigo regime; ou, em "monarquistas de pena", órfãos da sociedade de corte, incluídos aí, tanto membros do extinto Partido Conservador, como Afonso Taunay, Rio Branco e Eduardo Prado, quanto do movimento reformista, como Rodolfo Dantas, André Rebouças, Joaquim Nabuco e Afonso Celso Junior. Criaturas de uma cultura aristocrática e filhos da elite política imperial foram ceifados pelo golpe de 1889, quando em preparação para assumir o controle do país ${ }^{6}$ :

O desaparecimento do Império pôs abaixo sua carreira política, a perspectiva de futuro e o lastro social. Essa conjunção de estragos gerou amarguras intensas. Com sua repugnância pelo belicismo, nisso devedores de sua formação de corte, viram que seu terreno de briga era a palavra. Em ensaios, manifestos, romances, defenderam a tradição monárquica, que esboroava, e criticaram a republicana, que se construía, concentrados em duas tópicas: a forma da mudança (o golpe militar) e a arquitetura política do novo regime, de um lado, e os valores e o estilo de vida da sociedade republicana, de outro (Alonso, 2009, p.139).

Dentre os brasileiros que reforçariam suas concepções monárquicas, buscando no continente americano exemplos para reforçar suas posições, estariam, entre outros, Eduardo Prado, Joaquim Nabuco e Manoel de Oliveira Lima. Embora em alguns aspectos divergentes, esses intelectuais debatiam a política oficial "americanista" que se implementava desde a época da proclamação da República. Eram monarquistas com uma bagagem pessoal

jacobinismo se caracteriza - como foi dito de diversas formas - por uma 'maneira'”. (Vovelle, 2000, p. 2526.)

${ }^{6}$ Como seus sucedâneos franceses, "eles conservaram um prestígio tradicional, fortemente psicológico, [..] mas tinham perdido as bases reais do poder. Foram incapazes de manter seu estamento". (Auerbach, 2007, p. 247). 
predominantemente européia e exprimiram de maneira enérgica suas posições, opondo-se ou aos Estados Unidos, como Eduardo Prado, ou à América hispânica, como Nabuco e Oliveira Lima. Mas, ainda que a proposição monárquica tenha sido embalada num período reconhecidamente marcado por diferentes e acirradas polêmicas, pelas mais diferentes vozes, entre os intelectuais das mais diferentes orientações ideológicas - no tom ameno do consenso - , convém, contudo, não deixar que esse coro dos monarquistas obscureça a compreensão das diferentes razões e sensibilidades latentes às aparentemente unissonantes vozes dos seus defensores. A advertência de Karl Mannheim parece válida no contexto: "Palavras jamais significam a mesma coisa quando usadas por diferentes grupos, ainda que no mesmo país, e leves variações de sentido nos fornecem as melhores pistas para as diferentes tendências de pensamento numa comunidade" (Mannheim, 1986, p.81).

Assim, optamos por trabalhar com os textos de autores que foram escritos durante a primeira década republicana. A opção por agrupá-los decorre não tanto do fator cronológico, mas ao fato de que foram escritos num contexto de grande instabilidade institucional em relação ao novo regime. Como sabemos, o governo de Floriano fora muito conturbado: o militarismo, a crise econômica, a intervenção estrangeira dos Estados Unidos para conter a Revolta da Armada, a Revolta Federalista no Rio Grande do Sul, além do enfrentamento entre jacobinos e monarquistas em tumultos urbanos. A época era, para além de mudanças, de muitas críticas. Nesse sentido, Eduardo Prado aproveitaria para direcioná-las tanto sobre a nova ordem institucional quanto ao repertório de idéias que legitimavam o novo regime, qual seja, a crítica ao americanismo republicano - crítica essa que já vinha estampada no título do seu livro: A ilusão americana. Rui Barbosa, no calor da hora, aproveitaria a repercussão do livro de Eduardo Prado para criticar os rumos militaristas e próEstados Unidos que a república que ajudara a construir estava seguindo.

Já Joaquim Nabuco e Oliveira Lima, ambos monarquistas, que não aderiram de imediato ao novo regime, buscaram além da crítica institucional, pensar o lugar no Brasil no processo civilizatório e a principiar a discussão sobre o Pan-americanismo. Com a República, começávamos a nos afastar da Europa, mas começávamos também a olhar para a civilização que se desenvolvia no Novo Mundo. Nesta direção, na segunda parte deste texto, pretendemos 
compreender de que forma esses dois intelectuais construíram, ainda no ambiente conturbado dos primeiros anos da república, imagens diferenciadas sobre os Estados Unidos e a América Latina. Essas imagens pautavam-se, por um lado, na visão dos problemas e questões concomitantemente postas ao Brasil e aos demais países do subcontinente, formados em sua maioria por uma população mestiça, como o Brasil; e do outro, pelo modelo de república civilizada, moderna e composta predominantemente por uma população branca, representado pelos Estados Unidos.

Diante das imagens construídas por Nabuco e por Oliveira Lima - este, de modo muito mais explícito do que o primeiro - e das interpretações delas decorrentes, pensamos não ser infundado buscar demonstrar que a escolha pela aproximação com os Estados Unidos, em detrimento de uma aproximação com os demais países do continente, para esses autores, tinha estreita relação pautada pela questão racial e civilizacional do período. Procuraremos, dessa forma, jogar luz sobre esse aspecto do relacionamento entre o Brasil e os Estados Unidos, que se estabeleceu, nos primeiros anos do século XX, no interior do Pan-americanismo e tentar demonstrar que, ao terem em vista contribuir para os processos de construção do Estado-nação e de modernização do Brasil, esses autores construíram uma interpretação que via na solidariedade e na aproximação com o país do norte do continente a possibilidade de se equiparar com aquela civilização, diferentemente dos resultados possíveis com uma aproximação com os países latino-americanos.

\section{As primeiras críticas à "ilusão americana"}

Eduardo da Silva Prado (1860-1901) foi um dos mais ferrenhos críticos da República brasileira recém proclamada e da política Pan-americanista. Eduardo Prado era membro de uma das famílias mais ricas de São Paulo, cuja fortuna tinha origem na agricultura (açúcar e, principalmente café) e no comércio. Cresceu cercado pelo luxo do salão de sua mãe, Veridiana Prado, no bairro de Higienópolis, um dos pontos mais importantes de encontro da vida intelectual e artística da cidade. Depois de formar-se em Direito pela Faculdade do Largo de São Francisco em 1881, iniciou uma viagem ao redor do mundo: 
durante quatro anos visitou a Europa, o Oriente Médio e os Estados Unidos ${ }^{7}$. Em 1886 fixou residência em Paris, tornando-se o local um ponto de encontro favorito entre os intelectuais de língua portuguesa: freqüentavam o salão parisiense de Prado desde exilados literários como Eça de Queirós e Ramalho Ortigão, a brasileiros como Rio Branco, Domício da Gama e Joaquim Nabuco (Cf. Skidmore, 1994, p. 53-70).

Após a derrubada da monarquia, Eduardo Prado mergulhou num ataque frontal à república ${ }^{8}$. Inicia seu ataque às instituições republicanas já em 1889 , na Revista de Portugal (de dezembro de 1889 a junho de 1890) publicando uma série de artigos ácidos contra o novo regime, reunidos depois em livro intitulado Fastos da ditadura militar no Brasil. Nesses artigos, Prado "conseguiu realizar a primeira sistematização das críticas à República brasileira, contendo já os seus escritos a maioria dos elementos que caracterizaria todo o movimento monarquista" (Janotti, 1986, p. 30) ${ }^{9}$. Prado permaneceu dois anos na Europa depois de proclamada a república, lançando de lá suas criticas. Volta ao Brasil em 1892, tornando-se um ativo participante do movimento monarquista. No ano seguinte, publica o seu principal livro, A ilusão americana, de 1893 - cuja primeira edição foi confiscada pelo governo republicano ${ }^{10}$.

\footnotetext{
${ }^{7}$ Essas experiências lhes renderam a base de uma série de artigos de viagem sobre centros urbanos: "Chicago é a cidade mais brutal do mundo. Estou na realidade extenuado com a viagem e ansioso para ver-me livre deste país que é uma fornalha e onde para abrir-se a boca paga-se um dólar e outro para fechar-se. Decididamente o mundo é Paris". (PRADO, $1902-1903$ apud SKIDMORE, 1994, p. 54). Pode ter havido outro fator para que Prado atribuísse tanta antipatia aos Estados Unidos, como sugere Gilberto Freyre: "Há quem atribua - recolhemos a informação de pessoa idônea, antigo Ministro de Estado que teve acesso a documentação numerosa e a gossip quase oficioso sobre as atividades brasileiras no estrangeiro - o ódio sistemático em que se aguçou em Eduardo Prado a antipatia [...] aos Estados Unidos, a certa experiência infeliz que o ilustre paulista teria tido em barbearia elegante daquela República: erradamente tomado por negróide - era de fato muito moreno, podendo ser confundido com um indiano em trajo tropical - teriam Ihe recusado serviço na tal barbearia, alegando o 'color bar'. Que o estrangeiro desculpasse, mas aquela 'shop' era só para gentlemen brancos. O ressentimento pessoal, estendido a atitude de publicista, explicaria o antiianquismo sistemático que fez Eduardo Prado - na Europa tratado como um príncipe [...] escrever um dos livros mais veementes aparecidos no Brasil na época: A ilusão americana". (Freyre, 2000,p.152).

${ }^{8}$ A defesa apaixonada de Eduardo Prado pela Monarquia não encontrava ressonância em sua família. Eduardo era o quarto filho homem de Veridiana Prado. O mais velho, Antonio da Silva Prado, grande cafeicultor, teve intensa vida política: foi Ministro da Agricultura (1885), Ministro dos Negócios Estrangeiros (1888) e Conselheiro do Império. Abolicionista de última hora, aceitou a República, elegendo-se em 1890 deputado à Constituinte. Foi prefeito de São Paulo de 1899 a 1910 e, em 1926, com 86 anos, foi um dos fundadores do Partido Democrático de São Paulo. O segundo filho, Martinico Prado, também fazendeiro, era republicano de longa data. Caio, o terceiro, faleceu em 1889.

9 Os títulos são: "Destinos políticos do Brasil"; "Os acontecimentos do Brasil"; "Práticas e teorias da ditadura no Brasil".

${ }^{10} \mathrm{O}$ livro de Eduardo Prado (1860-1901) contra um relacionamento mais estreito com os Estados Unidos não foi bem visto no momento em que Floriano Peixoto buscava o apoio norte-americano para conter a ameaça dos seus oficiais rebelados, em um meio bastante conturbado, decorrente da Revolta da Armada. Quando esta fracassou, foi forçado, junto com outros monarquistas, a fugir do Brasil. Sob o decreto de sua prisão, Eduardo Prado deixa o Brasil em 1894 e, no ano seguinte, ao regressar, torna-se proprietário do jornal O Comércio de São Paulo, principal órgão, durante os seis anos seguintes, de disseminação da
} 
Eduardo Prado não teceu críticas apenas à República brasileira, mas estendeu-as a todas as repúblicas americanas, dos Estados Unidos aos países hispanos. A comparação extremamente negativa das repúblicas hispânicas serviria como mote para criticar o regime político brasileiro, como em artigo denominado "Agouros e Presságios" - escrito durante a Presidência de Prudente de Morais - ao comentar mais uma reeleição de Porfírio Díaz no México:

A forma republicana na América Ibérica, como nos demonstra a experiência de quase um século, é inevitavelmente militarista e pessoal. É uma fatalidade histórica a que não é licito fugir. Debalde se têm feito tentativas de governos civis. [...] Essa sombra apagada e triste, que se chama um presidente civil, foi quase sempre imposta aos leitores por algum caudilho, cansado de governar e que acha bom, por decência, interromper um pouco o seu governo [...]. Ora, o governo continua militarista sempre, embora o presidente não seja militar. [...] Uma república sul-americana, sem o seu competente homem militar, é uma coisa vaga, inquietante, é um estado de transição, um interregno triste e pouco duradouro (Prado, 1959, p. 65-68).

O Paraguai também foi alvo de suas críticas. Estreitamente ligado à visão oficial do Império que propagandeava o autoritarismo e a política agressiva de Solano López como responsáveis pela deflagração da Guerra do Paraguai, Prado conclui:

propaganda de restauração da monarquia e de ataques ao regime republicano. O jornal extinguiu-se em 1897, em meio ao clima antimonárquico exacerbado pelo conflito de Canudos, e Prado novamente deixa o país. Retorna em 1898, em um ambiente mais tranqüilo, com a presidência de Campos Salles, dividindo seus últimos anos de vida entre Paris e a capital brasileira, mantendo as suas concepções monarquistas. (Cf. Skidmore, 1994, p. 53-70). A proibição, pela ditadura de Floriano de A ilusão americana, de nada valeu. A obra ganharia ainda maior atualidade com o passar do tempo. O livro repercutiu, profundamente, na opinião pública brasileira, como reconheceu Dunshee de Abranches, jornalista, presidente da comissão de diplomacia da Câmara dos Deputados e ardoroso defensor da política realizada pelo Barão do Rio Branco, em obra dedicada a analisar a política exterior do Brasil: "A ilusão americana, famoso livro publicado no Brasil logo após a proclamação da República, produziu incontestavelmente uma larga repercussão em todo o país. [...] Fôra mesmo mais longe: propusera-se a demonstrar que, na grande República do setentrião, os males e os perigos para as outras nações do continente estavam tanto nas instituições quanto nos homens; tentara assim incitar os sentimentos patrióticos dos brasileiros, proclamando que muito mais pernicioso e voraz era o imperialismo "yankee" do que o imperialismo europeu; [...] concluía por augurar dias calamitosos e desesperados para os povos latinos que, nesta parte do mundo, acreditavam ter encontrado na doutrina de Monroe e nas gloriosas tradições liberais da mais poderosa das potências americanas, elementos vitoriosos e indestrutíveis para a segurança da sua autonomia política e consolidação sempre crescente das suas liberdades públicas". (Abranches,1945, p. 35-38). Dunshee de Abranches pronunciaria em 21 de Outubro de 1911 na Câmara dos Deputados, um enorme e exaltado discurso rebatendo as críticas feitas à atuação política do Barão do Rio Branco. Ver, Abranches, 1945, p. 137-202. 
Infeliz Paraguai! Bem vingado estás tu neste momento vendo que o Brasil, teu orgulhoso vencedor de outrora, é hoje o imitador do que tu foste há trinta anos! Os brasileiros, que tanto desprezaram os costumes semibárbaros da política paraguaia, têm hoje em casa o que tanta compaixão Ihes inspirava na casa de seus inimigos. Nem mesmo faltam os aduladores da ditadura, como os tinha López. (Prado, 1959, p. 105106)

Prado inverte, portanto, o argumento republicano de que a retenção da Monarquia era indício de atraso e que a criação da República lançaria o Brasil numa nova era marcada pela influência civilizadora do liberalismo republicano presente na América. Argumentava que fora o Império de Pedro II, aquela "flor exótica" no Novo Mundo que fazia do Brasil uma civilização singular, pois havia garantido a unidade da América portuguesa, num território mais vasto que o dos Estados Unidos continental.

Assim, ao apresentar a sua condenação à República brasileira, Prado teceu considerações concomitantemente sobre os Estados Unidos e os demais países hispano-americanos. Seu livro, A ilusão americana tornou-se o mais eloqüente tratado antiamericano surgido no país, onde alegava que o Brasil estava perdendo sua soberania política em virtude da "fraternidade" com os Estados Unidos, induzida pela República. Argumentava ainda que os republicanos haviam levado o país ao caos, tornando-o presa fácil para os desígnios expansionistas dos Estados Unidos, cuja constituição procuraram imitar. Prado tenta evidenciar por todo o livro que a história havia demonstrado a incompatibilidade fundamental entre os interesses brasileiros e os norteamericanos.

Já a América espanhola, segundo Eduardo Prado, ao adotar o modelo norte-americano por ocasião dos movimentos de independência durante 0 século XIX, teria renegado suas tradições. Interessante é observar que Prado acusa os Estados Unidos por terem uma política externa invasora, tirânica, arrogante e oportunista, enquanto as Repúblicas da América espanhola são, por outro lado, identificadas com o militarismo e o caudilhismo. Entendia como perda da identidade brasileira a imitação, pelos republicanos, de modelos políticos estrangeiros, da qual a Constituição de 1891 era o exemplo óbvio. Como seus vizinhos da América espanhola, o Brasil havia adotado em 1889 
o mesmo grande erro em que os hispano-americanos tinham caído no primeiro quarto do século, isto é, quando artificialmente se quis impor ao Brasil a fórmula norte-americana. [...] $\mathrm{E}$ nós, tardiamente, fomos tomar parte da fastidiosa e desalentadora tarefa em que vivem, há noventa anos, os hispanoamericanos, isto na longa, vã, tormentosa e já degradante e inútil tentativa, quase secular, de querer implantar na América Latina as instituições de uma raça estrangeira (Prado, 1957, p. 46).

Seu ataque à imitação das instituições norte-americanas era um meio também de atacar o principal aliado dos republicanos brasileiros, enquanto elogiava a Inglaterra, que apoiava os restauradores monarquistas. Prado via sem números de males na influência norte-americana no Brasil, inclusive a manutenção da escravidão durante o Império:

Não teríamos conservado por tanto tempo aquela instituição iníqua, se a maior nação da América não tivesse tentado legitimá-la, e se, da parte escravocrata dos Estados Unidos, não nos viesse o incentivo, se não chegasse até nós a notícia do que se dizia e do que se fazia nos Estados Unidos para defender a escravidão (PRADO, 1957, p. 169-170).

Em A ilusão americana, Eduardo Prado deixa explícito o seu repúdio ao Pan-americanismo: não eram apenas as diferenças histórico-culturais do Brasil em relação aos Estados Unidos que eram apontadas no livro, mas a diferença do Brasil em relação à América Hispânica, negando qualquer possibilidade de integração entre os países do continente americano: "A fraternidade americana é uma mentira. Tomemos as nações ibéricas da América. Há mais ódios, mais inimizades entre elas do que entre as nações da Europa" (Prado, 1957, p. 8). Sustentava essa premissa arrolando diversos conflitos - do México à Patagônia - envolvendo fundamentalmente disputas territoriais, além de elaborar um catálogo de agressões dos Estados Unidos à América Latina. Quanto ao Brasil, considerou que seus centros mais populosos, no litoral, estavam mais próximos da Europa, pela facilidade da viagem, do que da maior parte dos demais países americanos: "separado deles pela diversidade da origem e da língua; nem o Brasil físico, nem o Brasil moral formam um sistema com aquelas nações" (Prado, 1957, p. 10). 
Para reforçar a idéia de que o Brasil constituía uma unidade independente do restante da América, Prado apelou também para a suposta veracidade do mito da llha Brasil. Segundo o mito, o Brasil seria um território insulado, envolvido pelas águas de dois grandes rios - o Amazonas e o Prata -, cujas nascentes seriam num mesmo lago interior. O Brasil, imensa ilha ${ }^{11}$, formaria sozinho um continente, e só posteriormente teria se fixado às vertentes orientais dos Andes: "Esta junção é, porém, superficial; são propriamente suas e independentes as raízes profundas e as bases eternas do maciço brasileiro" (Prado, 1957, p.10). Ora, o movimento argumentativo de Prado é o de distinguir o Brasil português da América espanhola - que, para ele, eram sinônimos de guerras civis, revoluções, anarquia política, militarismo, autoritarismo, ditaduras, corrupção, ruína financeira - não bastavam as distinções lingüísticas, culturais, históricas, era necessária uma segregação natural, fruto dos desígnios divinos.

A grande distância entre Brasil e Estados Unidos era marcada, segundo Prado, pela diferença da raça, da religião, da índole, da língua, enfim, pela história e tradição dos dois povos (Cf. Prado, 1957, p. 7). A questão mais relevante era a discordância profunda com a opção latino-americana pelo regime republicano, o que, segundo ele, seria mera imitação das instituições norte-americanas. Salientava que os Estados Unidos não auxiliaram as independências das colônias ibero-americanas e que a tão invocada Doutrina Monroe não passava de uma estratégia política para intensificar o poder e a interferência dos Estados Unidos nas questões internas dos países americanos. Prado fez referências à inúmeras atitudes intervencionistas dos norteamericanos nos países latinos do continente: o apoio à separação do Texas e posterior anexação deste território aos Estados Unidos; a subseqüente guerra contra o México; o atentado norte-americano às Ilhas Malvinas em 1831, facilitando a ocupação posterior da ilha pelos ingleses; a usurpação do governo nicaragüense pelo flibusteiro William Walker, com o apoio norte-americano, e a posterior invasão de Honduras; o interesse dos Estados Unidos em construir o canal inter-oceânico; a pressão sobre os governos de diversos países do continente, pelo pagamento de indenizações por prejuízos a empresas e cidadãos norte-americanos, com ameaças de intervenção militar; e outras

\footnotetext{
${ }^{11}$ Sobre o mito da Ilha - Brasil, ver (Magnoli,1997), p. 45-61.
} 
situações francamente desfavoráveis aos países latino-americanos (Cf. Prado, 1957, p. 12-97). Diante desse quadro, afirma que "não há país latino-americano que não tenha sofrido as insolências e às vezes a rapinagem dos Estados Unidos" (Prado, 1957, p.93-94).

Prado procura, em sua obra, desconstruir a versão oficial sobre o Panamericanismo - integração fraterna dos países americanos, em benefício de todos - de forma contundente: desde a Doutrina Monroe, o objetivo dos Estados Unidos sempre foi o de conquistar terras e mercados no continente, em detrimento dos interesses e direitos dos outros países americanos, utilizando-se para isso de arrogância diplomática, e sempre que julgasse necessário, a força militar. A política Pan-americanista, segundo Prado, tinha como objetivo o escoamento da produção norte-americana que ultrapassasse a demanda interna e, no intuito de concretizar esse projeto, impor tratados de reciprocidade comercial a fim de abrir os mercados latino-americanos para os produtos norteamericanos, em situação de enorme vantagem sobre os produtos europeus ${ }^{12}$.

Embora reconhecesse os Estados Unidos como uma potência econômica possuía uma visão predominantemente negativa dos valores e do governo desse país. Enquanto julgava, por um lado, que o governo era formado por uma plutocracia que não manifestava preocupação em minimizar a pobreza de uma parcela significativa da população, por outro, condenava os aspectos sócioculturais do povo americano (uma vez que a pena de morte e o linchamento eram comuns), conforme nos expõe nessa passagem:

O espírito americano é um espírito de violência; o espírito latino, transmitido aos brasileiros, mais ou menos deturpado através dos séculos e dos amálgamas diversos do iberismo, é um espírito jurídico que vai, é verdade, à pulhice do bacharelismo, mas conserva sempre um certo respeito pela vida humana e pela liberdade. O rábula de aldeia é, sem dúvida, um ente inferior, mas em todo caso, é superior, como unidade social, ao capanga e ao mandão (Prado, 1957, p.175).

\footnotetext{
12 Prado foi também um dos grandes críticos do Convênio Aduaneiro de 1891. Sua posição é explícita nessa passagem: "em troca de um favor fictício e ilusório, em seguida a uma negociação em que a má-fé norte-americana se tornou evidente, o Brasil concedeu isenção de direitos às farinhas de trigo dos Estados Unidos, deu isenção a vários outros artigos americanos". (Prado, 1957, p. 150-151).
} 
Eduardo Prado, embora não use o termo imperialismo, ataca criticamente o capitalismo norte-americano e percebe a tendência que se manifestava cada vez mais forte no continente:

Hoje, o industrialismo ainda tem algumas esperanças de se salvar e o povo não tem ainda a consciência nítida da sua força. As dificuldades do presente já são, portanto, bastante graves para o capitalismo, e a plutocracia americana procura, a todo o transe, sair das suas dificuldades e para isso volta-se para o estrangeiro. É para o estrangeiro que os políticos norte-americanos querem abrir uma válvula para o excesso de produção (Prado, 1957, p. 141-142).

O objetivo principal, entretanto, de Eduardo Prado não foi combater o imperialismo norte-americano e, muito menos, o sistema capitalista, tanto é que defendeu as monarquias européias, também imperialistas e capitalistas, em vários momentos da sua obra. O fim primordial de $A$ ilusão americana era defender a monarquia e atacar o regime republicano e presidencialista no Brasil, uma vez que Prado considerava o regime monárquico a opção "natural" dos países latino-americanos, dadas as suas características histórico-culturais (Cf. Baggio, 1999, p. 67). Dessa perspectiva, via que, tanto para o Brasil quanto para os países hispano-americanos, a monarquia era a forma de governo mais adequada para assegurar a estabilidade política, a ordem, a paz, a unidade territorial e a prosperidade econômica. Assim, o Brasil teria abandonado em 1889 o regime monárquico, mais adequado à sua prosperidade, imitando as instituições norte-americanas, em detrimento de suas próprias tradições. Ainda, o histórico das trajetórias das repúblicas hispano-americanas, a partir das independências, marcadas por guerras civis, governos autoritários, militarismo e caudilhismo, auxiliavam Prado na defesa de suas posições, de onde conclui: "o furor imitativo dos Estados Unidos tem sido a ruína da América" (Prado, 1957, p. 44).

Ora, a América hispânica representava, desse modo, tudo o que o Brasil não deveria ser: republicano, militarista, violento. E era no que o Brasil, na visão de Prado, a partir de 1889, havia se transformado. A imagem da América hispânica como permanentemente violenta, politicamente instável, comandada por caudilhos e imersa na convulsão social povoou a visão brasileira sobre seus vizinhos e Eduardo Prado foi um dos intelectuais que colaboraram intensamente 
para esta interpretação. Além de se tornar uma obra símbolo da luta monarquista e anti-republicana, $A$ ilusão americana trouxe o elemento polêmico da propaganda anti-estadunidense, num momento muito delicado em que 0 Brasil tentava consolidar, tanto a sua política interna, com o novo regime republicano $^{13}$, quanto a sua política externa, na busca de uma maior aproximação com os Estados Unidos.

A crítica de Eduardo Prado arregimentaria novos prosélitos. Rui Barbosa, que participou ativamente das construções institucionais republicanas e que fora fortemente influenciado pelo pensamento político constitucional angloamericano, não vacilou, contudo, em apoiar as advertências de Eduardo Prado, cujo livro, - A ilusão americana - considerava "feito de ciência, verdade e patriotismo" (Barbosa, 1998, p. 93). Em uma série de artigos publicados no jornal A imprensa, ao longo de 1899, Rui Barbosa criticava ferozmente o monroísmo e a política intervencionista norte-americana que estava sendo realizada no continente. Segundo o autor, um pouco de reflexão e de história bastaria para

...advertir na facilidade com que, para os estados fracos, se converte em tutela a intrusão doméstica dos poderosos, [...] para saber que a Doutrina de Monroe no uso diplomático dos Estados Unidos, tivera, em todos os tempos, um caráter exclusivamente norte-americano, que a face por ela apresentada ao resto da América era puramente uma limitação da soberania das outras repúblicas (Barbosa, 1998, p. 94).

Rui Barbosa exprobrou o apelo do governo de Floriano Peixoto para a intervenção dos Estados Unidos na Revolta da Armada e a tentativa de erguer uma estátua de Monroe como sinal de reconhecimento:

A ditadura de 1893, na sua luta contra a violência das dificuldades interiores, estendeu mãos implorativas para o governo dos Estados Unidos. [...] Veio pronto o auxílio solicitado. A interposição da bandeira

\footnotetext{
${ }^{13}$ Gilberto Freyre assim se expressou sobre o debate em torno do pan-americanismo nos primeiros tempos da República: "[Eduardo Prado] Exagerou-se, é certo, em sua ianquifobia no livro, ainda hoje famoso, $A$ ilusão americana - ao mesmo tempo antiianque e anti-republicano; mas não faltava de todo fundamento histórico ou critério sociológico às críticas aos pan-americanistas brasileiros ingenuamente certos de vir a República integrar-nos como por mágica num sistema continental de nações de todas fraternas, em conseqüência de o constituírem repúblicas na sua maioria inspiradas no exemplo da anglo-saxônia. Só ingênuos, na verdade, deixariam de enxergar, nas relações dos Estados Unidos com a maioria das repúblicas que caricaturescamente lhes seguiam o exemplo, o desdém do forte pelos fracos; o desprezo de uma gente ordeira pelas turbulentas, suas vizinhas, aliás, por simples e superficial acidente". (Freyre, 2000,p. 191).
} 
estrelada cortou o litígio pendente entre as forças legais e as forças revolucionárias na baía do Rio de Janeiro. [...] Pouco depois do fácil resultado o almirante americano, cuja interferência no conflito esmagara a insurreição naval, deliciava os seus compatriotas, em Nova York, entre as manifestações espumosas de uma festa repercutida pelos jornais, com a reivindicação hilariante do triunfo sobre a esquadra brasileira rebelada. Mas nós não fomos ingratos. O júbilo da legalidade satisfeita deu-se pressa em coroar, entre os beneméritos da república brasileira, entre os seus salvadores, as imagens de Benham, Cleveland e Monroe (Barbosa, 1998, p. 100-101).

Os Estados Unidos, vedando o continente à cobiça da Europa, não fizeram mais que reservá-lo para os futuros empreendimentos de sua ambição (Cf. Barbosa, 1998, p. 102-103). A ilusão americana, segundo Rui, passara, no Brasil, por várias transformações sob a influência dos interesses políticos e da ignorância nacional. O autor se sentia no dever de desmascará-las, "porque a nossa consciência não se pode submeter à corresponsabilidade numa falácia, a que a história e a experiência se opõem" (Barbosa, 1998, p. 101). Rui Barbosa, forte opositor da Doutrina Monroe, previa que, com a vitória dos Estados Unidos sobre a Espanha, na guerra hispano-americana de 1898, a diplomacia européia procuraria um modus vivendi "adaptável à política imperialista da Casa Branca" (Barbosa, 1998, p. 95). No seu artigo de 9 de junho de 1899, intitulado "A história repete-se", o jurista chama a atenção para a paridade entre duas épocas: a do Império brasileiro, quando há mais de cinqüenta anos, o Brasil, o Peru, a Bolívia discutiram a navegação do rio Amazonas e temeram anexações pelos Estados Unidos, com a situação atual, que é "mutatis mutandis a mesma: a intervenção dos Estados Unidos em Cuba e a anexação voluntária do arquipélago de Havaí determinam a ressurreição da velha idéia, que condensa a suspeita do momento" (Barbosa, 1998, p. 113-114).

Mas, Rui Barbosa não deixaria de demonstrar também certa indignação pelas repúblicas latino-americanas, ao referir-se ao "desleixo latino-americano". Para ele, os latino-americanos teriam menosprezado a política de neocolonização que estava sendo empreendida pelos europeus e norteamericanos, pois, animados pelas reminiscências da sua emancipação "com a fatuidade, a imprevidência e a imaginação próprias das raças, cuidaram ter assegurado a sua independência para a eternidade" (Barbosa, 1998, p. 96). Chega a afirmar que a confiança dos latino-americanos decorria das 
reminiscências de noções das origens indígenas que teriam resistido à época da colonização hispânica, contra a incursão estrangeira. $O$ tom final do artigo conclama o continente a ser previdente e ressalta que uma aliança com os Estados Unidos trariam prejuízos ao resto da América. No entanto, embora Rui Barbosa fosse muito crítico à presença da política norte-americana no continente e principalmente, no Brasil, não deixa também de explicitar a forma hierárquica com que via as demais repúblicas latino-americanas. De forma bastante pessimista, quanto ao significado das relações com os Estados Unidos que se configura na Primeira República, Rui Barbosa previa para o Brasil um destino semelhante ao das demais repúblicas latino-americanas: "No caldeirão aparelhado ao pantagruelismo da política invasora, vai na mais confusa promiscuidade com índios e mestiços toda a descendência portuguesa e espanhola debaixo deste céu, e com as mais desafamadas, as mais fracas repúblicas deste continente, as melhores, ou as mais fortes, como o México, a Argentina e o Chile" (Barbosa, 1998, p. 78).

\section{Joaquim Nabuco e Oliveira Lima: os Estados Unidos como modelo de ordem civilizacional e institucional na América}

Ao nos debruçarmos sobre as tensões no interior do pensamento dos monarquistas brasileiros nos primórdios da República, percebemos que estes faziam leituras com diferentes gradações ressaltando a importância do regime anterior e da sociedade em que este se baseava frente à emergência e consolidação da forma de governo republicana. Impulsionados pela crítica de Eduardo Prado e de outros monarquistas, os porta-vozes do antigo regime procuraram refletir e ao mesmo tempo relacionar e avaliar a política externa brasileira frente aos seus novos pares republicanos no continente. $O$ fato era que embora desenvolvessem percepções a respeito do papel e da relação do Brasil com os países latino-americanos e os Estados Unidos partindo das suas convicções institucionais monárquicas, o contexto era, contudo, republicano.

É nesse sentido que talvez seja interessante analisar a articulação entre a forte defesa de uma volta à monarquia por Eduardo Prado e sua rejeição a qualquer Pan-americanismo que aproximasse o Brasil da grande potência republicana, os Estados Unidos. Assim, torna-se importante acompanhar de 
que modo Oliveira Lima e Nabuco embora sendo também monarquistas, divergiam de Prado ao defenderem e justificarem a política de aproximação com o país do norte de forma positiva.

Nos textos de Joaquim Nabuco que servem de fonte para o nosso trabalho é possível identificar a construção de uma imagem unificada da América do Sul com base em atributos negativos no que tange a vida pública desses países do subcontinente. Assim como a todas as repúblicas sulamericanas e à brasileira, o autor atribuía a sustentação do regime apenas à violência militar e ao militarismo dos seus presidentes. Recorrendo aos mecanismos políticos do Império brasileiro, Nabuco argumentaria que as repúblicas do subcontinente seriam endemicamente instáveis devido à ausência de instrumentos de mediação das facções em luta. Uma vez que o Poder Moderador fora abolido, seria o "elemento militar" aquele que ascenderia naturalmente e conduziria a política partidária: "substituíram o Imperador pelo Imperator [...]. Deodoro pelo simples fato de suceder ao Imperador ele se achou com os mesmos poderes, sem as normas, está visto" (Nabuco, 1890, p. 10 apud Alonso, 2009, p. 139) Diante do quadro endêmico das repúblicas sulamericanas, Nabuco não titubeia em traçar um prognóstico: "A República, nos países latino-americanos, é um governo no qual é essencial desistir da liberdade para obter a ordem" (Nabuco, 1890, p.14 apud Alonso, 2009, p.140).

É interessante, porém, verificar que Nabuco expressa sua aversão ao "americanismo" republicano, mas deixa claro através do qualificativo "SulAmericana" que não se referia à república anglo-saxônica na América. Lançando mão de um manifesto nacionalista contra 0 americanismo republicano, Nabuco diria:

Eu lastimo a atitude suicida da atual geração, arrastada por uma alucinação verbal, a de uma palavra - república, desacreditada perante o mundo inteiro quando acompanha o qualificativo - Sul Americana. [...] a esse plagiarismo Americano, devemos opor outro sentimentalismo natural, vivo, verdadeiro: o Brasileirismo (Nabuco, 1891, p. 4 apud Alonso, 2009, p. 140). (grifos do autor)

Não era de se estranhar que Joaquim Nabuco, um monarquista de pena, recorresse à escrita para combater a República e exaltar a Monarquia. Reagiria à República "no momento em que o passado nacional corria] risco de ser 
mutilado", recorrendo a estratégias: uma, seria o enaltecimento de feitos e de estadistas do passado, compondo sua versão da história do Segundo Reinado, sob a forma aparentemente inofensiva de uma biografia do pai ${ }^{14}$. Valeu-se também de outra estratégia, com dois livros publicados no calor da hora: Balmaceda (1895) e A intervenção estrangeira durante a revolta de 1893 $(1896)^{15}$.

O livro que nos interessa mais imediatamente da fase monarquista de Nabuco durante os primórdios da República é Balmaceda ${ }^{16}$. O livro expõe as suas críticas monarquistas sobre a República: valendo-se da crise chilena com analogias óbvias com a brasileira - para armar análise comparada de conjunturas políticas, Nabuco procurou refletir sobre Balmaceda com o objetivo de obter subsídios para tecer críticas ao regime republicano brasileiro e, mais especificamente, ao período militar de Deodoro da Fonseca e de Floriano Peixoto $^{17}$. Nessa obra expõe também o seu interesse pela América Latina, pois, desde o 15 de novembro, segundo Nabuco, o Brasil começava "a fazer parte de um sistema político mais vasto" (Nabuco, 1895, p. 212), o da América do Sul. No início do seu trabalho justificou o interesse pelo Chile ao afirmar que a cada dia tornava-se mais importante para os brasileiros "conhecer o estado político da América do Sul" (Nabuco, 1895, p. 7).

O período de 1886 a 1891 da história chilena foi o alvo do interesse de Nabuco. Confessou ser um admirador do Chile e o comparou ao Brasil, países que se destacariam como exceções no cenário latino-americano, afirmando que "há mais energia nacional [...] nessa estreita faixa comprida entre a

\footnotetext{
14 Um estadista do Império, obra na qual narra a história política do Segundo Reinado tendo como elemento organizador dos fatos a carreira política de seu pai, Nabuco de Araújo, cujo primeiro tomo ficou pronto em 1884, mas só veio a público em 1898 (Nabuco, 1997).

${ }^{15}$ O livro saiu como artigos no Jornal do Comércio, em agosto de 1895 e, em livro, no começo de 1896 . O assunto principal é a Revolta da Armada e o governo de Floriano. Valendo-se de documentação primária, sobretudo artigos de jornal, o objetivo era político: avaliar a sociedade e as instituições republicanas pela ótica imperial. Publicado já no governo de Prudente de Moraes, a conjuntura permitiria aos monarquistas voltarem à cena na crítica aos republicanos. Nabuco carregou nas tintas, numa verve monarquista que opunha a barbárie republicana à civilização imperial. A paixão pela revolta está na dedicatória do livro a Augusto de Castilho, capitão do navio que asilou os revoltosos monarquistas (Nabuco,1990a).

${ }^{16}$ Trata-se da reunião, pelo autor, de uma série de artigos publicados no Jornal do Comércio, de janeiro a março daquele ano, nos quais Nabuco analisava a questão da deposição do presidente chileno, em 1891, a partir da obra de Julio Bañados Espinosa, Balmaceda, Su Gobierno y La Revolución de 1891.

17 Nos limites do nosso trabalho não abordaremos os argumentos monarquistas de Nabuco em Balmaceda construídos através do paralelismo entre os acontecimentos no Chile e as analogias com a República no Brasil. A ênfase recairá sobre a argumentação construída por Nabuco em relação a sua visão da América Hispânica já nos primórdios da República. A reconstrução da imagem das Repúblicas sul-americanas por Nabuco em Balmaceda será fundamental para compreendermos as concepções posteriores de Nabuco à frente da Embaixada brasileira em Washington, já adepto da República.
} 
Cordilheira e o Pacífico do que em todo o resto da América do Sul". Nesse sentido, Nabuco afirma que

\begin{abstract}
...apesar de sermos nós [o Brasil] a sociedade sem exceção alguma a mais igualitária do mundo, e de ser o Chile, pelo contrário, uma aristocracia política, tínhamos a mesma continuidade de ordem, de governo parlamentar, de liberdade civil, de pureza administrativa, de seriedade, decoro e dignidade oficial. Um e outro governo eram exceções genuínas na América do Sul, saliências de terra firme entre ondas revoltas e ensanguentadas (Nabuco, 1895, p. 3).
\end{abstract}

Os dois países seriam "saliências de terra firme entre ondas revoltas e ensanguentadas", ou seja, a monarquia brasileira e a república chilena seriam exemplos de ordem e estabilidade, contrastando com os demais países da América Latina, marcados pelas turbulências políticas e pelas guerras civis. Brasil e Chile tiveram que superar crises que colocaram em risco, segundo Nabuco, suas tradições políticas: o Brasil, durante o período de consolidação do regime republicano, com o domínio dos militares no comando da vida pública entre 1889 e 1894 e o Chile, durante o governo de Balmaceda. Demonstrava-se assim, afirmava Nabuco, a tese que os monarquistas sempre sustentaram contra os republicanos: a perda da liberdade e a corrupção da república, tanto no Brasil quanto no Chile:

Figurava-se tão paradoxal animarem-se os Republicanos com os resultados do Chile como se animarem com os da América do Norte, porque o Chile, ainda que de raça espanhola, era tanto uma exceção como os Estados Unidos - exceção que se podia considerar um capricho de ordem moral na formação da América do Sul, como há aparentemente tanto capricho na sua estrutura geológica (Nabuco, 1895, p. 208).

$\mathrm{Na}$ forma de um "capricho" ficava naturalizada no autor a excepcionalidade do Chile, o qual, ainda que formado pela mesma raça cujas supostas características conformavam a imagem negativa da América hispânica, aproximava-se de algum modo do corpo social saxônico da América do norte - única nação, conforme Nabuco, a qual caiu bem as vestimentas da república. 
Nesse sentido, importa-nos aqui, menos o tema da inadaptação institucional, o qual pode ser posto nas contas das posições monarquistasparlamentares do autor, rebatendo a República, do que o contraste construído entre, de um lado, nacionalidades débeis, "em menoridade permanente", com "tradições sem resistência" e, de outro, uma nacionalidade forte, cuja opinião e organicidade política colocam-se acima de qualquer governo pessoal. Nabuco desenvolve tal comparação no que toca a ordem institucional relacionada às qualidades inatas do corpo nacional das Repúblicas sul-americanas e dos Estados Unidos:

Em nossos países onde a nação se mantém em menoridade permanente, as liberdades, os direitos de cada um, o patrimônio de todos, vivem resguardados apenas por alguns princípios, por algumas tradições ou costumes, que não passam de barreiras morais, sem resistência e que o menor abalo deita por terra. A esses países, onde a lei é frágil, não se adaptam instituições que só pode tolerar uma nação como a Norte-Americana (Nabuco, 1895, p. 49).

Em Joaquim Nabuco é possível perceber que a imagem da América Latina aparece como uma incógnita em relação ao avanço, posto que inexorável, da civilização universal. A imagem do subcontinente se constitui com base em atributos negativos no tocante à vida pública dos países latinoamericanos. Ao percebermos os termos com os quais Nabuco trabalha, podemos ter claro como o autor constrói a imagem do subcontinente como uma porção inferior da América, refratária à civilização:

De fato, dado o progresso da Moral universal, não é possível que a civilização assista indefinidamente impassível ao desperdício de força e atividade humana que se dá em tão grande escala em uma das mais consideráveis seções do globo, como é a América Latina. A manutenção de um vasto Continente em estado permanente de desgoverno, de anarquia, é um fato que dentro de certo tempo há de atrair forçosamente a atenção do mundo, como afinal a atraiu o desaproveitamento da África (Nabuco, 1895, p. 212).

Os atributos negativos - "desperdício", "desaproveitamento", "desgoverno" - enunciam um subcontinente à margem dos mais elevados valores da civilização, e até mesmo sob certo sentido, "selvagem" na comparação recorrente com a África. Nesse sentido, Nabuco não deixa de 
indagar quanto à perspectiva futura da América Latina: "como se fará a redenção dos países centro e sul americanos? Onde acharão eles amparo contra seus governos extortores? Como se fará nascer e crescer em cada um deles a consciência do Direito, da Liberdade, da Lei, que neles não existem, porque não podem ter sanção alguma?"(Nabuco, 1895, p. 212)

Nabuco interpretaria o episódio do governo de Balmaceda e sua deposição no Chile como fenômeno típico da história e do cenário político contemporâneo da América do Sul, formulando assim, uma imagem constituída predominantemente sob atributos negativos. Nessa direção, condenando o reformismo balmacedista: "o pescador infeliz, cuja rede apanhara no fundo do mar a garrafa em que estava encerrado o terrível gênio sul-americano, e que o soltara em terra chilena foi o próprio Balmaceda" (Nabuco, 1895, p. 77). Dentro desse raciocínio, Nabuco, baseado no exemplo do Chile iria reforçar de forma ainda mais evidente a construção de uma imagem unificadora do subcontinente sob a égide de uma padronização negativa. Notemos os termos que Nabuco utiliza para destacar a potencialidade de desordem pública, quase eterna:

... em toda a América do Sul, há neste momento, como tem havido sempre, uma porção de revoluções à espera somente de um pretexto para rebentar. Os golpes de Estado são ocasiões preciosas, de primeira classe, que despertam o maior entusiasmo revolucionário, e por isso o presidente que fornece aos ânimos já mal refreados dos seus contrários um motivo dessa ordem, lança a um paiol de pólvora o morrão aceso (Nabuco, 1895, p. 187). (grifo nosso)

A imagem de um subcontinente afetado por uma doença crônica, portanto, enfermo, conduz a análise de Nabuco para a apresentação de um diagnóstico, quando afirma que "de muitas doenças graves costuma-se dizer que foi no princípio um resfriamento mal curado; a história da América do Sul parece não ter sido outra coisa senão uma revolução mal curada", cujo prognóstico não poderia ser de caráter mais monarquista: "O que a América do Sul precisa é de um extenso Poder Moderador, um Poder que exerça a função arbitral entre partidos intransigentes" (Nabuco, 1895, p. 205).

Ora, ainda mais expressivo é o painel comparativo traçado por Nabuco no que tange a ordem institucional, revelando claramente como o autor via hierarquicamente as duas Américas, afirmando que as instituições norte- 
americanas são impróprias para as raças latinas: "desde que se sente em conflito com o Congresso, Balmaceda não procede como um presidente dos Estados Unidos, consultando as opiniões mais autorizadas e mais seguras em matéria constitucional; procede à verdadeira moda sul-americana, ouvindo os comandantes de Corpos" (Nabuco, 1895, 195).

Em outro texto, "O dever dos monarquistas" - escrito no calor da hora e publicado originalmente também em 1895, no Rio de Janeiro - Nabuco responde extensamente à carta do Almirante Jaceguay, publicada no Jornal do Comércio, em setembro daquele mesmo ano, sob o título Dever do momento, na qual o almirante incitava Nabuco à colaboração com o novo regime. Nabuco não deixaria de tecer um paralelo entre república e instabilidade institucional na América do Sul:

... muito mais extensa e profunda do que a degeneração republicana da monarquia no Brasil não é a degeneração monárquica da república em toda a América do Sul? A verdade é que em um meio onde não existe a pressão social é impossível que a forma de governo conserve perfeitos todos os seus característicos, seja ela a monarquia, seja muito menos, a república (Nabuco, 1990b, p.40).

Afora o tema de momento do texto que refletia a discussão sobre a adaptabilidade institucional, Nabuco parece insinuar a tese de que, frente a um organismo social débil, não é mesmo possível a adaptação perfeita de nenhuma ordem institucional, ou no limite, poderíamos dizer, civilizada, como seria o caso da adaptação institucional na América Latina (Cf. Silveira, 2003, p. 224-225). O mal latino-americano não seria de natureza essencialmente institucional e a resolução não seria encontrada na ordem do político, pois, "não são as instituições que não têm raízes; é o solo que não tem consistência e cujas areias o menor vento revolve" (Nabuco, 1990b, p. 43). Se o mal não é da ordem do político e das instituições, a que Nabuco se refere como "solo [in]consistente" na América do Sul? Tudo indica que se trataria de um mal, uma inferioridade na comparação com a América saxônica - ao mesmo tempo natural e persistente.

Veja-se que, respaldado na observação de Tocqueville, Nabuco indaga de seu interlocutor, o almirante Jaceguay: "que impressão não the causarão estas dolorosas palavras caídas de uma pena tão prevenida a favor da 
democracia como era a de Tocqueville: 'quando penso na alternativa de miséria e de crime em que vivem aqueles países sou forçado a pensar que para eles o despotismo seria um benefício"'? (Nabuco, 1990b, p. 51)

Respaldado na observação de Tocqueville, Nabuco reforçará a imagem de que à América Latina caberia a única solução possível, a ditadura, e que ao privar essa parte do continente da Liberdade, privá-la-ia também de um dos pilares da construção da idéia de América. Não sendo de se estranhar assim, que a idéia de Liberdade coubesse, nesse sentido, apenas aos Estados Unidos. Notemos deste modo, como Nabuco diferencia o Brasil da América Latina para poder se espelhar na outra superior América: "a ordem porém que o torrão brasileiro deve querer produzir não deve ser a planta que cresce estéril na América Latina e sim a que na América Saxônia dá a liberdade como fruto" (Nabuco, 1990b, p. 48).

Assim, o despotismo aparece para Nabuco como a solução para as "sociedades debilitadas" da América Latina. Porém, o autor constrói uma imagem diferenciada de um Brasil frente a essa América. Embora este país, por princípios naturais e históricos, compusesse uma unidade latino-americana, dela ao mesmo tempo deveria apartar-se da imagem dicotômica tradicional América portuguesa/ América hispânica para poder espelhar-se na outra exemplar América, a do norte.

Ora, na perspectiva dos monarquistas, o americanismo republicano enfileiraria o Brasil com a outra América, a Espanhola, rumo ao caudilhismo, ao despotismo, ao militarismo e quem sabe, até mesmo à fragmentação do país. Eduardo Prado e Joaquim Nabuco representavam os velhos temores da elite imperial que aspirava elevar o Império à altura das monarquias européias e afastá-las das repúblicas abaixo do Equador. Nabuco em suas conclusões revela um dramático tom pessimista, deixando evidente que a América Latina estaria longe, ainda que não apenas naquele momento histórico, de alcançar a civilização:

Um problema de tal complexidade não poderá ser resolvido pela própria geração que o formular. À distância em que estamos do tempo em que ele há de amadurecer, a forte refração dos preconceitos atuais não deixa imaginar o modo que a civilização há de encontrar para se introduzir no nosso Continente. [...] Não será a absorção pela Europa, a menos que se entenda no sentido de uma recolonização Européia da América com elementos que asseguram o predomínio das novas 
aluviões, porque é mais do que provável que a imigração se realize no próximo século em escala tal que os nossos organismos anêmicos, alguns mesmos raquíticos, não tenham capacidade para assimilá-la (Nabuco, 1895, p. 212-213).

Joaquim Nabuco examinava a América Latina, refratária segundo o autor, ao avanço do processo civilizatório, diante das duas fontes universais de expansão desse processo: a Europa e, a partir da República, os Estados Unidos. É importante notar que Nabuco escrevera Balmaceda antes da guerrahispano-americana que marcaria a expansão imperialista dos Estados Unidos. Nesse sentido, é preciso perceber o modo como Nabuco interpretava a Doutrina Monroe e o Pan-americanismo, descartando inicialmente e de modo definitivo a possibilidade de que o Velho Continente, pelos instrumentos da recolonização ou do protetorado, viesse a constituir-se no agente "introdutor de um processo mais estável da civilização" no subcontinente. Ao findar o século XIX, Nabuco afirmava que

É difícil imaginar uma alteração no equilíbrio europeu que forçasse a Europa a reconquistar a América ou a sujeitá-la, como fez com a África e a Ásia, à sua direção e ao seu governo. Pode-se ter como certo [...] que a Europa deixará o Novo Mundo fazer bancarrota com os capitais e interesses que ela lhe houver confiado, sem pensar um só instante em compensações territoriais ou em estender através do Atlântico a sua área de influência (Nabuco, 1895, p. 213).

Porém, se o risco, ou o que o autor entende como "solução civilizatória possível" - da colonização ou do protetorado europeu - estavam afastados, Nabuco levanta inevitavelmente novas indagações: "Se a solução não pode ser o protetorado europeu, será por acaso o Monroísmo? Os Estados Unidos, que já assumiram a proteção do Continente, desde que se comprometeram a defendê-lo contra as invasões da Europa, sentirão um dia que essa garantia Ihes dá direitos ou que lhes impõe deveres?" (Nabuco, 1895, p. 213-214). Nesses termos, Nabuco parece rejeitar que os Estados Unidos viessem a praticar intervenções diretas, no sentido da colonização ou do protetorado em larga escala no continente. Buscando respaldar sua posição, Nabuco usa significativamente o exemplo brasileiro, com a questão do momento, qual seja, a de uma reação monárquica interna. Assevera, nesse sentido, que "seria 
preciso desconhecer o caráter nacional do povo americano para se supor, por exemplo, que se o Brasil restaurasse a sua monarquia, os Estados Unidos impugnariam essa volta às nossas antigas instituições". Novamente aqui, Nabuco ressalta a incompatibilidade institucional da República no continente americano, cuja exceção seria os Estados Unidos: "Se eles impedissem o Brasil de ter o governo que the parecesse melhor, estavam moralmente obrigados a governá-lo sob sua responsabilidade; não tinham o direito de condenar um povo ao despotismo e à anarquia por causa de um tipo de instituições, para as quais só eles possuem a resistência e o corretivo preciso. Governá-lo, porém, - como?" (Nabuco, 1895, p. 214)

Devemos perceber, deste modo, que Nabuco, na sua representação original do monroísmo, na década final do século XIX, por um lado, reforça a noção fundamental da superioridade naturalizada da civilização angloamericana, posta nos atributos do povo e no sistema de governo, cuja adaptação perfeita se deve à índole natural daquele povo; por outro, faz repousar sobre este "caráter superior", a justificativa isolacionista daquela raça e a impossibilidade histórica de que o monroísmo se desdobrasse nas soluções representadas pelo colonialismo, pelo protetorado e pelas anexações pelos quais se havia constituído a Federação. Assim, afastada a solução colonial em larga escala, os "Estados Unidos [...] rejeitariam para Estados da União cada um dos candidatos da América Latina", pois, segundo Nabuco, "a nação americana está convencida de que todo acréscimo de população, de hábitos, crenças e índole inteiramente outras, causaria um profundo desequilíbrio em seu sistema de governo e uma incalculável deterioração de sua raça" (Nabuco, 1895, p. 214-215).

Dessa forma, Nabuco apontará como uma solução possível para a questão latino-americana uma espécie de pan-americanismo de origem latina. A solução para o problema teria que "ser procurada dentro mesmo de cada um dos nossos países, mas depende da formação em torno deles de uma opinião interessada em seu resgate, que auxilie os esforços, ou quando mais não seja registre os sacrifícios, dos que em qualquer parte lutarem pela causa comum". A imagem de um pan-americanismo latino passa por uma visão aristocrática, nos moldes do liberalismo do autor, onde destaca que o possível avanço civilizatório do subcontinente estaria atrelado a existência "em todos esses 
países [de] homens cuja cultura rivaliza com a mais brilhante cultura européia e que podem formar a Liga Liberal do Continente" (Nabuco, 1895, p. 215).

Posteriormente, Nabuco abandonará a idéia de que tal União dos países latino-americanos - fundada em uma opinião comum da elite intelectual e política em prol do progresso, da paz e da estabilidade - poderiam constituir-se como definidoras de um padrão civilizatório. Assim, o padrão civilizatório latinoamericano não poderia constituir-se efetivamente, de forma isolada, mas apenas no interior de um Pan-americanismo de dimensão hemisférica e de iniciativa norte-americana, fundado, portanto, no monroísmo, sob o risco, menos calculado do que inevitável, da perda de uma unidade latinoamericana $^{18}$.

Assim, a política do Pan-americanismo, iniciada no final do século XIX para incentivar a integração dos países americanos sob a influência dos Estados Unidos, foi discutida em várias obras publicadas desde esse período até a década de 20. Não por acaso, em finais do século XIX e no processo mais amplo de americanização da República, as representações dos Estados Unidos como modelo de ordem civilizacional e institucional, começariam a ganhar forma em diversos intelectuais, passando a se constituir em um grande interesse nacional, como testemunha Oliveira Lima:

No Brasil fala-se ou muito bem ou muito mal dos Estados Unidos. Apontam-nos os seus admiradores como o único modelo a seguir sem discrepâncias, o melhor figurino a copiar nos mais ligeiros pormenores [...]. Os seus detratores culpam-nos de todos os crimes, desde a ambição devoradora de terras e nacionalidades, até à corrupção política e social mais desbragada. À parte os exageros do fanatismo, a verdade está incomparavelmente mais com os primeiros. É pelo menos o que me ensinou uma estada de três anos no grande país americano, que eu tanto desejaria ver imitado pelo meu no ingente progresso material ${ }^{19}$ (Oliveira Lima, 1899, p.1).

\footnotetext{
${ }^{18}$ Nesse sentido, não há para Nabuco uma longa história com a idéia de monroísmo, será somente na defesa do direito do Brasil na questão com a Guiana Inglesa que a concepção de uma política monroísta para o Brasil começa a fazer sentido, porque ela se torna palpável e passível de efetividade ganhando uma real dimensão política. Quanto ao conceito de "pan-americanista", atribuído às concepções de Nabuco à frente da embaixada brasileira em Washington, "como um ardente defensor dessa causa nos termos em que usualmente se julga, ou seja, de um missionário da união e solidariedade incondicional de todos os países americanos, encontra barreiras em sua visão hierarquizada dos países, na sua idéia de relacionamentos preferenciais independentes e na perseguição de interesses nacionais brasileiros alheios a de outros"(Pereira, 2006 p. 124).

${ }^{19} \mathrm{O}$ livro trata-se de uma reunião de artigos publicados na Revista Brasileira durante os anos de 1896, 1897, 1898 e 1899 e de trechos de correspondência publicadas pelo Jornal do Commercio do Rio de
} 
Entre os monarquistas, Joaquim Nabuco e Oliveira Lima ${ }^{20}$ foram exemplos significativos daqueles que construíram uma imagem nova sobre a condição modelar e de superioridade da civilização norte-americana no continente, de inteiro acordo, portanto, com a tendência da política exterior brasileira na Primeira República.

Ao escrever sobre os Estados Unidos, Oliveira Lima não escondia seu deslumbramento e o impacto causado após um período de permanência naquele país. Cotejou Brasil e Estados Unidos para concluir pela desvantagem do primeiro em todos os aspectos que analisou: sociais, econômicos, políticos e culturais. O impacto da comparação parecia maior quando se considerava que os dois países eram frutos do moderno capitalismo europeu:

$\mathrm{Na}$ América do Norte apoderou-se de mim e a breve trecho converteu-se quase numa obsessão, uma forte impressão do nosso atraso, que na Europa eu nunca havia experimentado, acostumados como justamente andamos a considerá-la um antiqüíssimo campo de experiências e de progressos. Do outro lado do Atlântico porém, num país de civilização tão moderna quanto o Brasil, a comparação impõese irresistivelmente, em nosso grave desabono, com o seu cortejo de considerações psicológicas e sociológicas (Oliveira Lima, 1899, p.17).

O conjunto de artigos que compõe o livro de impressões de Oliveira Lima é "paradigmático da [sua] concepção evolucionista da história". (Malatian, 2001, p. 124). Os Estados Unidos representavam o ápice do progresso possível a uma nação naquele momento em termos materiais, políticos e culturais. Sua interpretação tinha como pressuposto a convicção da superioridade do mundo anglo-saxão em relação ao mundo ibérico, identificado como "trópicos", onde o autor não encontrava condições geográficas nem raciais para que as nações alcançassem elevado grau de evolução. Oliveira Lima encontraria nos Estados Unidos respostas para questões que

Janeiro, nos anos de 1896, 1897 e 1898. O livro alcançou público amplo tanto nos Estados Unidos, no Brasil e mesmo em outros países. (Cf. Malatian, 2001, p. 122-123).

20 É necessário ressaltar que o ingresso de Oliveira Lima no serviço diplomático ocorreu num contexto de reorganização da diplomacia brasileira em seus quadros e direcionamentos. Isso teria levado o jovem Oliveira Lima a empreender uma estratégia para garantir que não pairassem dúvidas sobre sua identificação com a República e conseqüentemente, não afetasse o seu trânsito no Ministério das Relações Exteriores do Governo Provisório da República, preocupação que abandonou completamente em 1903, direcionando e declarando-se abertamente favorável à monarquia. (Cf. Malatian, 2001, p. 80). 
permaneciam insolúveis no Brasil: a comparação do "figurino político" das repúblicas do continente, a imigração européia controlada e branqueadora, a política externa audaciosa e afirmativa, a concessão de direitos civis, porém não políticos aos negros.

De fato, Oliveira Lima trouxe à superfície nessa obra uma questão que começaria a ocupar papel central nas duas primeiras décadas republicanas e, de vários modos determinantes, nas construções dos autores que serão examinados ao longo do nosso trabalho. Trata-se da aplicação da noção de raça nas formas de representação do padrão civilizatório norte-americano, particularmente na definição civilizacional daquele país, em contraste com a brasileira e a da América hispânica.

Como nos lembra Silveira, em relação a Joaquim Nabuco, precisamos considerar os compromissos políticos do autor em passado recente ${ }^{21}$, o que evidentemente não o deixaria em uma posição confortável ao tratar a questão de extrema atualidade e relevância no contexto - da superioridade da raça branca e os possíveis efeitos de uma miscigenação com "raças inferiores", ou mesmo das conseqüências sociais da presença destas como componentes da população de um país (Cf. Silveira, 2003, p. 168). Entretanto, Nabuco não deixaria de mencionar o choque racial na América, asseverando, nesse sentido, que para o norte-americano,

a igualdade humana fica dentro dos limites da raça; já não falando do chim ou do negro - que seria classificado, se vencesse o instinto americano, em uma ordem diferente da do homem - nunca ninguém convenceria o livre cidadão dos Estados Unidos, de que o seu vizinho do México ou de Cuba, ou os emigrantes analfabetos e os indigentes que ele repele dos seus portos, são seus iguais (Nabuco, 1963, p. 142) ${ }^{22}$.

\footnotetext{
21 Embora os textos referentes ao período abolicionista de Nabuco não sejam aqui objeto de análise, podemos localizar a ambigüidade que a todo momento perpassa a obra do autor, como por exemplo, em certas passagens em que transparece a hierarquização das raças: "Muitas das influências da escravidão podem ser atribuídas à raça negra, ao seu desenvolvimento mental atrasado, aos seus instintos bárbaros ainda, às suas superstições grosseiras"; já em outra passagem, parece tentar mitigar constantemente a importância da influência racial na formação nacional: "o mau elemento da população não foi a raça negra, mas essa raça reduzida ao cativeiro". (Nabuco, 2000, p. 101 e 100, respectivamente).

${ }^{22}$ A citação encontra-se em Minha formação. Trata-se de coletânea de artigos publicados primeiramente no Comércio de São Paulo, em 1895, posteriormente pela Revista Brasileira, sendo reunidos em livro pelo autor em 1900. Segundo Nabuco, "a data do livro para leitura deve assim ser 1893-99, havendo neles idéias, modos de ver, estados de espíritos, de cada um desses anos. Tudo o que se diz sobre os Estados Unidos e a Inglaterra foi escrito antes das guerras de Cuba e do Transvaal, que marcam uma nova era para os dois países" (Nabuco, 1963, p. 3).
} 
À primeira vista, temos a impressão de que a constatação de Nabuco aponta para a atribuição de uma característica negativa do princípio de igualdade do povo norte-americano. Porém, cabe-nos a dúvida de que, ao percebermos que para a elite intelectual brasileira - provável público interpretativo de Nabuco - o atraso era posto como sendo decorrente da presença de "raças inferiores", sendo predominante a noção moderna da superioridade da raça branca - a constatação de Nabuco, não seria, em reverso, interpretada no Brasil justamente como o motivo da força e do poder do povo branco norte-americano, sendo portanto, algo a ser seguido?

Em outra passagem, embora sem concordar inteiramente com seus termos, Nabuco oferece destaque a um trecho de uma entrevista concedida por Herbert Spencer a um periódico americano. No trecho reproduzido por Joaquim Nabuco em Minha formação, referia Spencer sobre o futuro dos Estados Unidos, onde dizia: "de verdades biológicas deve-se inferir que a mistura eventual das variedades aliadas da raça ariana que formam a população [americana] hão de produzir um mais poderoso tipo de homem que tem existido até hoje". (Nabuco, 1963, p. 156). Mesmo sem concordar inteiramente com os termos de Spencer, Nabuco não deixa, no entanto, de destacar a idéia corrente de raça biológica e, ao comentá-la, afirma que "é possível que seja aquela a lei biológica da mistura ariana", embora o tenha feito para destacar mais uma vez o fato de que a Europa "ainda" suplantava os Estados Unidos como modelo de civilização.

Apesar de considerarmos aqui Joaquim Nabuco e Oliveira Lima como pertencentes a um mesmo pólo no debate a respeito das interpretações e imagens construídas favoravelmente aos Estados Unidos em relação àquelas construídas em detrimento à América Latina, isto não quer dizer, porém, que não reconheçamos as diferenças entre esses dois autores. Diferenças existem e são muitas. A opção por agrupá-los aqui partiu da escolha de suas obras, produzidas no contexto de grande instabilidade política no país. Nesse sentido, pensamos ser interessante analisarmos as interpretações surgidas nos primeiros anos do novo regime, momento em que os autores se voltaram imediatamente para os exemplos fornecidos no continente americano. 
Talvez aqui se tornem mais visíveis as tensões e contradições no interior do monarquismo na época, pois tanto Oliveira Lima quanto Nabuco embora sendo monarquistas, acrescentariam novos elementos para justificarem a política de aproximação com os Estados Unidos, o que não vemos em Eduardo Prado. Neste sentido, torna-se fundamental reconhecer a ênfase que Oliveira Lima atribui aos elementos geográficos e principalmente raciais para demonstrar comparativamente, como esses argumentos estavam presentes no modo de pensar também de Nabuco - é claro que percebidos de maneira menos nítida pelo forte envolvimento deste com o movimento abolicionista. Ora, se Oliveira Lima e Nabuco partilhavam do argumento de Eduardo Prado pela defesa da monarquia como fator responsável pela preservação da integridade territorial, da estabilidade política e da depuração racial frente ao horror dos países vizinhos da América do Sul, a isso acrescentariam os argumentos de origem racial. Não deixariam também de salientar e propor o modelo de soluções implantado para essa questão no caso norte-americano buscando desse modo, a justificativa para que pudessem afirmar que 0 Brasil e os Estados Unidos deveriam continuar se aproximando, não obstante as diferenças nas formas de governo.

Assim, Nabuco realiza nos primeiros anos da República uma crítica mais explícita às instituições das repúblicas sul-americanas e apenas tangencia o debate sobre raça. Ora, não podemos nos esquecer da trajetória intelectual e política do autor: Joaquim Nabuco, considerado um dos líderes da campanha abolicionista, não poderia operar com os conceitos de raça tão abertamente. No entanto, por um lado, se Nabuco não opera diretamente com os termos relacionados à "raça", não deixa de estabelecer, por outro, a hierarquia entre os povos do continente, através de seus níveis civilizacionais, associando instabilidade institucional com a "índole natural do povo" latino-americano. É aqui, portanto, que já podemos reconhecer que, para Nabuco, se inevitavelmente, tornáramos uma nação republicana, deveríamos nos espelhar e nos aproximar da república do norte, exemplo de estabilidade institucional e de civilização no continente.

Por sua vez, Oliveira Lima utiliza-se do viés explicativo de "raça" e "meio" para caracterizar a América Latina e ressaltar a superioridade da América Anglo-saxônica de modo muito mais explícito, construindo um discurso no qual 
as operações com os termos relacionados à temática racial aparecem de modo mais claro do que em Nabuco. Nessa direção, nos afirma Oliveira Lima:

A grandeza dos Estados Unidos tem sido, como é corrente, constituída pela considerável imigração européia, além do gênio ativo e inventivo da própria raça colonizadora. Este fator é também essencial. A diferença de resultado na colonização dos dois continentes, ou melhor, da América Inglesa e da América Latina, deve mesmo filiar-se mais que tudo nas qualidades das respectivas raças conquistadoras (Oliveira Lima, 1899, p. 53-54).

As noções determinantes do universo intelectual de Oliveira Lima - raça e meio - sustentaram argumentos sobre a superioridade natural de um povo, nesse caso, o anglo-saxão, sobre outro - os latino-americanos. As formas de representação do povo americano derivaram de modo bastante direto, da noção da herança racial: no contraste Brasil/Estados Unidos, a representação do passado, referente aos processos de colonização nas Américas, introduziram um modo de naturalizar e internalizar - com o fundo biologista do conceito de raça e determinista da noção de meio - a desigualdade e o contraste entre as duas unidades continentais representadas. Oliveira Lima construirá um discurso que não deixaria dúvidas quanto a sua forma de ver as populações inferiores e os problemas derivados da presença negra no continente.

A princípio, a análise de Oliveira Lima parte do que considera um problema comum para o Brasil e os Estados Unidos no final do século XIX. Esse problema comum, bem como a sua resolução, seria a justificativa para os brasileiros guiarem o olhar para aquele país: "tudo concorre [...] para tornar especialmente interessante para nós o problema do futuro social dos Africanos e seus descendentes nos dois grandes países do continente americano, que [...] foram [...] os que maior quinhão receberam desta imigração forçada". De modo muito claro afirma assim, qual seria o mal do qual a América padecia, atestando ainda, a quase unanimidade de opiniões a respeito: "o negro na América é um mal, da mesma forma que foi a escravidão uma peste social". "Ninguém, penso, cogitará em negá-lo". A associação com a experiência pósescravidão brasileira e a norte-americana é transposta diretamente nas páginas de Oliveira Lima: "o Sul dos Estados Unidos, cuja decadência ainda dura desde 
a guerra da Separação, malgrado a capacidade de trabalho da raça branca e especialmente dos Nortistas que afluíram após o triunfo federal, e malgrado também a opulência natural do solo" (Oliveira Lima, 1899, p. 19). Daí, a identificação do "problema" norte-americano com o brasileiro é direta, pois "o Sul dos Estados Unidos é o nosso Norte. Ali penetra ainda dificilmente a imigração estrangeira, receosa do clima [...] e não menos receosa da concorrência do negro" (Oliveira Lima, 1899, p. 51).

Os problemas derivados da presença negra eram essencialmente os mesmos, tanto no Brasil quanto nos Estados Unidos, o que os diferia eram as formas de relacionamento que os brancos latinos e os anglo-saxões estabeleceram com os negros. Se, de um lado, nos Estados Unidos, "a sorte dos trabalhadores [negros] era infinitamente pior do que no Brasil”; do outro lado, no Brasil, "o trabalho escravo era mercê da superior predisposição ao afeto da raça latina e do seu menor desprezo pelas raças inferiores" (Oliveira Lima, 1899, p. 21). Nesse sentido, diante da comparação de tratamentos dispensados ao negro, Oliveira Lima cogita a possibilidade de o modelo anglosaxão de relações inter-raciais ser adotado frente ao modelo latino, no Brasil ${ }^{23}$.

Ao incorporar, em larga medida, algumas noções do segregacionismo sulista norte-americano, Oliveira Lima apontaria assim, os equívocos e os acertos do tratamento dos brancos dispensado aos negros nos Estados Unidos, como modelo potencial para o Brasil. Um dos equívocos estaria por um lado, na multiplicação do negro; do outro, ao atribuir-lhes direitos políticos: "o perigo do negro, se por um lado está na sua multiplicação, por outro lado, reside no erro cometido pelos vencedores de 1865 atribuindo-lhes direitos políticos". Oliveira Lima salienta as formas de tratamento das "raças inferiores", aparecendo como ideal o limite físico da segregação representada pelas reservas indígenas. Lamenta, porém sua inaplicabilidade à população negra,

\footnotetext{
23 Uma questão candente para os republicanos brasileiros da época era a definição da identidade nacional em termos de raça. Com sua obra sobre os Estados Unidos, Oliveira Lima recebera de José Veríssimo crítica publicada na Revista Literária do Jornal do Comércio, com o título de "O país extraordinário". Em meio aos elogios da análise, percebe-se, porém, a discordância antiamericana de José Veríssimo com relação ao julgamento, que considerava deslumbrado, de Oliveira Lima em relação aos Estados Unidos. Ao seu ver, a obra era excessivamente otimista e benevolente em relação àquele país e revelava a adesão ao universo racista norte-americano, aceitado sem distanciamento crítico: "é curioso que Brasileiro, certamente sem os preconceitos de raça que aqui, quando existam, são superficiais e insignificantes, o observador entrou tanto no ponto de vista americano, sofreu tanto a influência do meio, que se não escandaliza por forma alguma, antes aceita como naturais e normais os termos em que os yankees puseram a questão". (Veríssimo, 1899 apud Malatian, 2001, p. 130).
} 
pois estavam inseridas no sistema produtivo, eram de maior número e acobertadas, ainda que equivocamente, segundo o autor, pela cidadania: "não existe uma questão índia porque os selvagens, acantonados em suas reservas, [...] das contendas públicas só conhecem o uísque e os cobertores que lhes fornecem os contrabandistas e comissionados do governo" (Oliveira Lima, 1899 , p. 31). Quanto aos acertos que os Estados Unidos obtiveram no tratamento da população negra, Oliveira Lima destaca a diluição da população negra pelos vários estados, no sentido de evitar a excessiva concentração nos estados sulistas:

O êxodo da população negra tem sido [...] tentado nos Estados Unidos desde o estabelecimento da República da Libéria. Ainda em 1889-90 discutiu-se no Senado Federal um bill [...] para providenciar acerca de emigração do Sul da população de cor, derramando-a entre a população dos outros estados, impelindo-a para as terras devolutas do Oeste ou, sonho delicioso, despejando-a nas costas africanas (Oliveira Lima, 1899, p. 43).

Desse modo, Oliveira Lima, ao traçar os "atributos naturais" da raça negra também estabelece de forma igualmente naturalizada qual seria 0 possível lugar a ser ocupado pelos negros em uma sociedade moderna, como eram os Estados Unidos e como deveria ser o Brasil: "o negro como trabalhador e dirigido pelo branco oferece, na opinião dos entendidos, qualidades preciosas pela sua obediência e rija musculatura. [...] Para a vida agrícola, sobretudo independente, não possui requisitos bastantes" (Oliveira Lima, p. 31-32).

A questão do "problema negro" para Oliveira Lima estava estreitamente associada à imigração européia para os Estados Unidos. Primeiramente, o autor distingue um marco zero diferenciador no Novo Mundo, onde a imigração européia dos anglo-saxões à América do Norte é associada com a formação da nacionalidade e do modelo civilizatório superior desenvolvido nos Estados Unidos. Nesse sentido, Oliveira Lima associará, já no processo colonizador, os dois conceitos - meio e raça - para revelar o traço inevitável da superioridade anglo-saxã. No processo de colonização, os anglo-saxões superaram até mesmo as intempéries naturais: os colonizadores ingleses e portugueses depararam-se com obstáculos "idênticos", ainda que a natureza "era 
manifestamente mais clemente no continente sul que no norte". Deste modo, se alguma diferença de condições existia, ela fora favorável à colonização portuguesa, mas a diferente composição racial que se formou na América Anglo-saxã e na América latina teria sido a responsável pelos assimétricos graus de civilização. No interior desse processo e como seu fruto, o Brasil formaria assim

um corpo anêmico e fraco, porque gerado por uma raça açodada, com uma vontade mais ardente que tenaz, de fé proselítica e ganância tumultuosa, que desembarcava sôfrega por alcançar num momento a conversão em massa do gentio e as riquezas fabulosas dos sonhos medievais. Os Estados Unidos formam pelo contrário o produto forte, próspero, admirável, de uma raça mais nova, mais cheia de seiva, menos pejada de antiguidade e de tradições, e que consigo levava o senso positivo da vida (Oliveira Lima, 1899, p. 56).

É interessante observar como Oliveira Lima trabalha com representações do Brasil e dos Estados Unidos que ganham significado quando expressas por pares de oposição. Enquanto a primeira, "anêmica e fraca", resultante dos cruzamentos com "raças inferiores", a segunda, "forte, próspera, admirável", deriva da preocupação entre os norte-americanos de uma "certa seleção consciente no qual entram como fatores o vigor físico e a limpeza de origem", revelando assim, as assimetrias existentes entre os povos do Novo Mundo. Antes de significar um puro esnobismo, a preservação da pureza da raça, segundo Oliveira Lima, adquiriu entre os norte-americanos, uma significação mais elevada, contribuindo para impulsionar esse povo para o progresso, oposto ao Brasil, em que o cruzamento com outras raças constituiu fator de atraso:

Procurou-se sempre conservar pura a raça branca, e mesmo entre esta exerce-se uma certa seleção consciente na qual entram como fatores o vigor físico e a limpeza de origem. Por isso a raça americana vinga e prospera num meio cujas condições eram indubitavelmente inferiores às nossas, em vez de definhar fisicamente $e$ atrofiar-se moralmente (Oliveira Lima, 1899, p. 212).

Vemos, desse modo, a questão racial posta no centro do modelo imigratório americano, como meio substancial de preservação da pureza 
branca dos primeiros anglo-saxões aportados na América. Tanto o papel crucial da imigração européia quanto a capacidade singular de assimilação de emigrantes de raças consideradas "não degradantes" da América são sublinhadas por Oliveira Lima como "o nervo do progresso americano, não só pelo que diz respeito ao aumento da população e à possibilidade para esta de conservar-se afastada de misturas degradantes, como pelo que toca à disseminação civilizadora e à adoção entusiástica pelos forasteiros da nova pátria" (Oliveira Lima, 1899, p. 86).

Oliveira Lima enfatiza de modo evidente as possibilidades de que a imigração tal como ocorrera e ocorria nos Estados Unidos se constituísse num modelo imitável pelo Brasil. Dessa maneira, o "problema negro" se constituía numa relação singular com um modelo civilizatório para o Brasil, ou seja, a imigração européia. Por isso, os Estados Unidos, entre outros motivos, foram tão importantes para o debate intelectual brasileiro na Primeira República. Oliveira Lima, empenhado na discussão sobre a necessidade de "branqueamento" do país e sobre o futuro possível dos negros na sociedade brasileira não deixaria de trazer para o debate nacional o papel que os Estados Unidos desempenhavam, ao menos potencialmente, no enfrentamento de um problema representado como grave e análogo ao brasileiro. Papel pelo qual, os Estados Unidos e sua sociedade, branca, recebiam a marca natural de superioridade e a condição universal de modelo, digno de ser imitado. Assim, o padrão civilizatório dos Estados Unidos deveria ser seguido de perto, pois a imagem construída por Oliveira Lima quanto à possibilidade de futuro dos países latinos na América só indicaria sinais de tragédia: "cairão assim quase todos os nossos países latino-americanos, se não os salvarem a sã imigração européia, com todas as conseqüências morais que comporta, e a prática das virtudes que explicam o poderio da raça saxônia, dentro das terras tropicais habitadas pelas raças inferiores" (Oliveira Lima, 1899, p. 457).

Em concordância com Nabuco, Oliveira Lima representa a posição brasileira no continente como singular devido ao regime monárquico que teria conseguido manter a estabilidade a despeito das revoltosas repúblicas do continente. O autor insere em uma tradição histórica a "geral simpatia" brasileira pelos Estados Unidos, ao mesmo tempo em que representa uma suposta imagem do Brasil naquele país, a qual consagra o critério diferenciador 
brasileiro - a paz interna monárquica - relativamente ao mundo hispânico, visto como um todo: "por mais que nos tenhamos esforçado por estragar uma reputação adquirida em muitos anos de paz interna, somos tidos [nos Estados Unidos] na conta de gente de mais juízo do que o comum dos Hispanoamericanos: as nossas revoluções são em média decenais e as deles anuais". Notemos também todo o discurso onde se privilegia a desconfiança entre os países do continente, ressaltando por outro lado, a precedência do Brasil na amizade com os Estados Unidos: "dá-se também o fato de havermos ininterruptamente manifestado geral simpatia pela República anglo-saxônica, apesar da nossa prévia organização monárquica, ao passo que no México [...] os Estados Unidos só encontravam justificada desconfiança, no Chile e na Argentina, ciúme e mesmo má vontade alimentada por vários incidentes" (Oliveira Lima, 1899, p. 435).

Além da histórica proximidade do Brasil e Estados Unidos, Oliveira Lima aponta motivos contemporâneos que seriam também responsáveis pela suposta imagem privilegiada do Brasil nos Estados Unidos. A série de ações representadas por Oliveira Lima foram apresentados como "o sincero apoio prestado na conferência pan-americana [de 1889] pela nossa delegação à delegação norte-americana; a co-participação no tratado geral de arbitramento; a boa vontade internacional expressa na confecção de um convênio de reciprocidade; finalmente o auxílio moral prestado aos intentos americanos nas diversas fases da questão cubana" (Oliveira Lima, 1899, p. 436).

Daqui desponta a preocupação de Oliveira Lima de reforçar a imagem de uma aproximação contínua entre Brasil e Estados Unidos, ressaltando que todas as questões que porventura, neste século, foram aventadas entre os dois países, foram amigavelmente ajustadas, e nem poderiam ter sido diferentes, pois, não teriam passado de acidentes triviais na vida das nações, "cuja regulação é a moeda corrente da diplomacia e apenas requer um pouco de sangue frio e ausência de prevenções" (Oliveira Lima, 1899, 437). Dentre vários desses incidentes, o autor descreve sua contestação a uma crítica à aproximação Brasil/Estados Unidos, da já mencionada obra de Eduardo Prado, A ilusão americana, cujas críticas percorreriam o ambiente da Primeira República: 
O sr. Eduardo Prado faz de sua má vontade aos Estados Unidos um dos artigos da profissão de fé monárquica no Brasil. Discordando antecipadamente deste modo de ver, um dos maiores estadistas do Império, o Conselheiro Paulino José Soares de Souza, visconde do Uruguai, ao dar na Nota de 22 de abril de 1851 ao ministro americano David Tod as razões por que o Governo Brasileiro julgava desnecessária a celebração de um tratado proposto por esse diplomata para regular as relações mercantis e outras entre os dois países, referia-se à República como a "mais poderosa nação americana, da qual tem o Brasil recebido não equívocas provas de consideração e simpatia, e com a qual tem cultivado relações de subida importância para ambos os países" ${ }^{24}$ (Oliveira Lima, 1899, p. 442).

Oliveira Lima compreendeu e sintetizou bem sobre quais termos estavam fundadas as relações materiais entre os dois países. Se o Brasil procurava consumidores para a sua produção natural e agrícola nos Estados Unidos; os Estados Unidos, por sua vez, procurava deslocar para o Brasil o excesso de sua produção industrial: "A maior parte do nosso café e da nossa borracha, um pouco do nosso açúcar [...] para aqui [Estados Unidos] vêem; para lá [Brasil] buscam eles mandar em maior escala o que nos fornecem os países manufatureiros europeus" (Oliveira Lima, 1899, p. 447).

Aludindo novamente a Eduardo Prado, assevera Oliveira Lima que "à Ilusão americana é conveniente contrapor a Realidade americana". Ou seja, embora os Estados Unidos fossem uma nação mais populosa, muito mais rica e muito mais forte do que o Brasil, a boa amizade, a união entre os dois países não significariam a subalternação desse último, como apontou Eduardo Prado, já que não éramos, de acordo com Oliveira Lima, uma "quantité negligeable", mas "a primeira potência da América do Sul pelas dimensões [...], pela importância do nosso comércio, pelas reservas da nossa riqueza" (Oliveira Lima, 1899, p. 450-451). Vale observar que a assimetria na relação é apresentada e imediatamente convertida, no plano da representação, em "amizade" e "união", tanto no que se refere aos interesses nacionais de ambos os pólos quanto no que se refere às relações do continente, no sentido da construção ideal do Pan-americanismo.

\footnotetext{
${ }^{24}$ Cabe sublinhar aqui, que apesar de Oliveira Lima procurar dar sustentabilidade histórica aos seus argumentos, utilizando-se de uma citação de Paulino José Soares de Souza, o fato é que na realidade, as relações do Brasil com os Estados Unidos durante o Império foram bem conturbadas, a exemplo da discussão da navegação do rio Amazonas.
} 
Oliveira Lima representa a posição brasileira no interior do quadro da construção ideal do Pan-americanismo, como singular, posta entre a autoridade norte-americana e a necessária e conveniente adesão hispânica ao sistema. Novamente em concordância com Nabuco, Oliveira Lima coloca o país na condição de interlocutor privilegiado da potência norte-americana em contraste com as objeções de desconfiança apresentadas dos países hispânicos, ressaltando assim, uma troca de conveniências na relação bilateral entre o Brasil e os Estados Unidos, ao invés das relações multilaterais que deveriam caracterizar o Pan-americanismo:

Aos Estados Unidos convém a nossa simpatia, que já Ihes tem sido útil e sem a qual eles correriam muito o risco de isolamento no continente meridional. A nós convém-nos não menos a simpatia da grande República, cujo proceder tem sido sempre tão liso e correto para conosco. A época é pouca para isolamentos (Oliveira Lima, 1899, p. 451).

É, assim, na perspectiva da preponderância dos Estados Unidos no continente que Oliveira Lima examinaria a Doutrina Monroe e suas possíveis conseqüências na construção do sistema pan-americano. O autor interpretaria o sentido do monroísmo como componente da política externa dos Estados Unidos, inapelavelmente, ligado ao interesse nacional do país: "a política externa dos Estados Unidos resumiu-se toda em dois princípios: neutralidade nas questões européias (princípio dos dois hemisférios) e preponderância nas questões americanas, precisado o primeiro por Washington, o segundo formulado por Monroe" (Oliveira Lima, 1899, p. 362). Destacando o sentido histórico da unilateralidade da Doutrina Monroe, Oliveira Lima articula dois elementos, primeiro, o caráter unilateral, explicado historicamente e ancorado nos argumentos da superioridade anglo-saxônica; de outro, as conseqüências civilizatórias, política e moralmente benéficas para o continente como um todo:

Em 1823 os Estados Unidos teriam agido motu proprio, sem esperar a reclamação de algumas das demais nações do continente; mas então, quando as nações latino-americanas estavam sem forma cristalina, e saídas de um estado mais degradante que a escravidão [...] o seu papel de paladino ex officio estava traçado e só envolvia benefício e proveito sem humilhação nem rebaixamento. A República anglosaxônica havia efetivamente chamado a si a defesa da democracia, 
regime que hoje ainda é ela a única na América a compreender e praticar na sua plenitude (Oliveira Lima, 1899, p. 378-379).

Nesse sentido, é possível flagrar em Oliveira Lima, de um lado, a naturalização do expansionismo norte-americano e, de outro, a caracterização de tal expansionismo como missão civilizatória. A própria superioridade da civilização norte-americana é posta na base explicativa do domínio que se interpreta como absolutamente "inevitável" e, nesse sentido, não submetido a condicionamentos sócio-históricos de algum modo politicamente contornáveis, inscrevendo-se na ordem, portanto, dos fenômenos naturalizados, sobretudo em sua férrea inevitabilidade:

Neste fim de século [...] nenhuma República latino-americana pode [...], mesmo imperfeitamente, ombrear com os Estados Unidos na colonização integrada, desenvolvimento industrial, adiantamento intelectual, [...] vigor, opulência e esplendor. A preponderância pois da nação norte-americana no continente é mais do que uma intenção manifesta, é uma condição necessária, um resultado fatal, a que não há fugir (Oliveira Lima, 1899, p. 365-366).

A interpretação de Oliveira Lima, produzida imediatamente no contexto e pelo resultado da guerra com a Espanha, com as anexações do Havaí, de Porto Rico, das Filipinas e com o protetorado em projeto sobre Cuba, segue afirmando que a própria "superioridade natural" das tradições políticoinstitucionais e do povo americano, "conseguirá fornecer às anexações uma cor justificada e esforço civilizador e não de uma mera ostentação de poder" (Oliveira Lima, 1899, p. 426). O autor tece a consideração de que a América Latina poderia contar com uma base firme de apoio da nação norte-americana, no que esta tinha de superior, para fazer frente a uma expansão que se fizesse fundada exclusivamente na força bruta dos interesses materiais dos Estados Unidos.

Ora, Oliveira Lima reafirmaria que dependeria dos países latinoamericanos não se tornarem dependentes dos Estados Unidos, pois, era fundamental que aliassem o espírito de trabalho, de paz interna e de tolerância a fim de tratar da prosperidade nacional e afastar o pavor das anexações. A explicação para anexação não poderia ter fundo mais determinista: aqueles menos preparados ou que aparentassem sinal de fraqueza serão 
inevitavelmente submetidos ao poderio dos mais fortes. Seguindo a tendência dominante no contexto internacional de seu tempo, Oliveira Lima colocava como natural a expansão imperialista:

As anexações espreitam sempre os países fracos, gastos e corrompidos, como a Polônia, a Turquia e a China; não se afoitam em ameaçar os países ordeiros, laboriosos e progressivos. A desagregação só dá-se nos organismos sociais decrépitos ou incapazes de prosperar, nunca nos organismos sadios e florescentes. Proclamar receios de absorção é dar testemunho da própria impotência para os conflitos da civilização (Oliveira Lima, 1899, p. 452-453).

Reafirma ainda Oliveira Lima, que a "civilização nos trópicos há [...] que ser continuamente imposta, dirigida ou fiscalizada [...]; uma vez abandonada a si própria, mesmo quando exercida pela raça branca [...] tende a abismar-se na degradação ambiente, como o provam [...] as colônias britânicas nas Antilhas, e o demonstram [...] quase todas as nações latinas do continente" (Oliveira Lima, 1899, p. 427). É baseado, portanto, na idéia de superioridade da raça saxônica como garantia de uma expansão civilizatória, por um lado, e de outro, pela garantia de um agente fiscalizador, em virtude da "degradação tropical" mais uma vez ressaltando de forma negativa o continente americano - que o autor elegerá como potência colonizadora-civilizadora da raça saxônia, os Estados Unidos, pois "ninguém de boa-fé contesta [...] que saberão colonizar melhor do que a Espanha, isto é, que saberão dotar as ex-colônias espanholas com condições de progresso material diferentes das que atualmente possuem" (Oliveira Lima, 1899, p. 484). Nesse sentido, propõe uma comparação:

Havaí, que é de fato mais de meio século uma colônia americana, de um lado, e do outro Cuba e Porto Rico, aí estão para serem cotejados e responderem por si a interrogação [...]. Comparemse as ruas asseadas de Honolulu, os seus vistosos edifícios, a sua salubridade, o seu ar de prosperidade e riqueza, com a imundície em que se achava Santiago ou a Havana, as suas casas leprosas, as suas epidemias, o seu ar de abandono e de pobreza (Oliveira Lima, 1899, p. 485).

Torna-se desnecessário diante do exposto ressaltar a força do contraste civilizatório apontado por Oliveira Lima, do mesmo modo que realça as 
realizações do governo militar norte-americano em Cuba. Cabe ressaltar que, influenciado pelas relações amistosas entre o Brasil e os Estados Unidos, que haviam passado pela arbitragem norte-americana favorável ao Brasil na questão do território das Missões (1895), Oliveira Lima legitimava, com seus artigos, a concretização da aplicação da Doutrina de Monroe em sua versão atualizada de contraponto ao imperialismo europeu na América. A todas essas investidas, Oliveira Lima deu seu aval, aliás, reproduzindo as atitudes do governo brasileiro, o único da América Latina que, alegando neutralidade, demonstrou simpatia pelos Estados Unidos e chegou a ceder-Ihes navios durante a Guerra Hispano-Americana.

Ora, a proposição de Oliveira Lima não poderia ser mais clara em termos de um ideal civilizatório para a América, impondo-se do povo superior para o inferior uma limpeza civilizatória, material e espiritual. Entretanto, ressalta 0 autor, o povo inferior ainda permaneceria irredutível na sua inferioridade natural, uma vez que "mais difícil do que as condições materiais é [...] mudar a natureza do povo cubano, o seu espírito volátil [...], leviano e irrequieto". Aliada a superioridade civilizatória dos norte-americanos estaria a sua benevolente atenção à autonomia das nações americanas: "muito resta por fazer e quão precisa é uma mão de ferro que saiba ao mesmo tempo respeitar as liberdades essenciais, as quais os Americanos estão absolutamente dispostos a não imolar" (Oliveira Lima, 1899, p. 489-490).

É com base em tal quadro de representação das Américas que Joaquim Nabuco e Oliveira Lima construíram uma imagem dos Estados Unidos como padrão civilizatório e de ordenamento institucional. Essa imagem foi construída a partir de conceitos, atuais naquele contexto, como raça, meio, progresso e atraso e contribuiu para naturalizar a noção de superioridade associada à civilização saxônica na América. O painel composto associava a idéia de inferioridade à América Latina, vista como um todo - que se manifestava na supostamente crônica incapacidade para o auto-governo - sempre na comparação com a América saxônica. Tal inferioridade era relativizada, no interior desse painel, por meio da construção da idéia de superioridade do Brasil frente à América hispânica, de modo geral, o que se fundava no passado monárquico, posto como fundamento da estabilidade interna e, a partir dessa, do progresso futuro. 
O que pretendemos deixar claro aqui também é que o discurso de Oliveira Lima e de Joaquim Nabuco não resultou apenas de uma mera constatação, mas antes, procuraram responder aos problemas prementes na sociedade de sua época. Como bem sintetizou Gildo Marçal Brandão, "nenhuma grande constelação de idéias pode ser compreendida sem levar em conta os problemas históricos aos quais tenta dar respostas e sem atentar para as formas específicas em que é formulada e discutida; ao mesmo tempo, que nenhuma grande constelação de idéias pode ser inteiramente resolvidas em seu contexto" (Brandão, 2007, p. 33). De todo modo, tanto Oliveira Lima quanto Joaquim Nabuco emprestavam sua posição de poder intelectual para dar contundência e atualidade à forma de representação da civilização americana, considerada a relação Brasil/Estados Unidos, frente à elite brasileira, intérprete e receptora dessa forma de representação.

Joaquim Nabuco e Oliveira Lima ao tratarem das formas de representação do padrão civilizatório norte-americano, em contraste com o brasileiro e dos demais países americanos, contribuíram para a construção da imagem da superioridade da civilização norte-americana na América. Através de suas representações discursivas, fundamentaram a construção da americanização republicana, embora isso significasse colocar os Estados Unidos na posição modelar de República-mãe da América e não necessariamente, ampliar o escopo de representações e relações positivas com os demais países americanos (Cf. Silveira, 2003, p. 298). Nesse sentido, ambos os discursos se constituíram a partir dos mais atualizados e complexos instrumentais de análise, os quais carregaram consigo uma série de noções típicas do universo intelectual do período considerado.

Assim, um novo projeto político-intelectual se consubstanciara com o Manifesto Republicano em 1870 com a indicação do pertencimento do Brasil à América. Outro elemento também marcaria profundamente o início da nossa República: a entrada de Rio Branco como Ministro das Relações Exteriores (1902) e a criação da embaixada brasileira em Washington (1905). Concomitantemente com esses acontecimentos, as teorias racialistas/evolucionistas compartilhariam o mesmo quadro da Primeira 
República ${ }^{25}$. Nesse sentido, a convergência de aspirações nacionais com os fatores internacionais - a americanização da república, o Pan-americanismo e o exemplo da modernização política e social oferecida pelos Estados Unidos, em contraste com o das demais repúblicas americanas - propiciou solo fértil para novas interpretações, inquietações e formulações de projetos para a nação pelos intelectuais brasileiros no início da República.

Diante desse turbilhão de temas que fervilhavam nos primeiros anos da Primeira República, os intelectuais brasileiros que atuavam na arena política, direta ou indiretamente, ou, como intérpretes da realidade social e divulgadores de visões de mundo, necessitavam de novos argumentos intelectuais para reforçar suas posições. Novas explicações que "reorganizassem e reexplicassem a natureza de seu ambiente social e institucional, [...] e que ligassem seu trabalho a uma significativa meta poderia proporcionar condições para arregimentar novos prosélitos" (Graham, 1973, p. 241). Merece destaque, portanto, num momento em que as relações do Brasil com os Estados Unidos tomavam novo rumo num contexto de expansão do monroísmo sob a égide pan-americanista, a imagem da superioridade anglo-saxã na América entre os pensadores do período.

Convém ressaltar que, a partir de 1905, Oliveira Lima seria o crítico mais importante da aproximação Brasi//Estados Unidos, sob a condução do primeiro embaixador brasileiro em Washington, Joaquim Nabuco. Ao contrário deste que via na amizade com os norte-americanos um elemento central da nossa política externa, além de sua idealização histórica e perene, Oliveira Lima entendia a relação com os Estados Unidos de forma calculada. Advertia que no horizonte de nossa política externa a relação Brasil/Estados Unidos deveria ser pensada em termos de interesse e assimetrias de poder no interior do continente. E aqui se afastava peremptoriamente de Nabuco: a aproximação com os Estados Unidos deveria ser vista com cautela e não como um imperativo. Sua preocupação advinha da interpretação que os Estados Unidos faziam da Doutrina Monroe, utilizando-a como uma política exclusiva de aporte unilateral no continente.

\footnotetext{
${ }^{25}$ A expressão consagrada de Sílvio Romero, o "bando de idéias novas que esvoaçou sobre nós de todos os pontos do horizonte", correspondia a absorção, a partir de 1870, no cenário brasileiro, de teorias de pensamento até então desconhecidas, como o positivismo, o evolucionismo e o darwinismo.
} 
Alertava também Oliveira Lima que a condição política para que a inevitável liderança política dos Estados Unidos não se convertesse no interior do sistema Pan-americano em predomínio absoluto era a unidade latinoamericana. Diferentemente de Nabuco, que defendia a liderança hemisférica dos Estados Unidos, Oliveira Lima via como necessária, a pan-americanização da Doutrina Monroe, ou seja, era necessária a cooperação entre "os mais prósperos" da América Latina para uma associação posterior com os Estados Unidos, de modo a afastar a orientação predominante rooseveltiana, que dificultava naquele momento, a efetivação de um sistema continental.

Apesar de crítico a uma aproximação com os Estados Unidos, Oliveira Lima não concordava, todavia, com uma aproximação com a América Latina, como um todo, nem tampouco possuía uma visão otimista desta parte do continente. É visível nesse sentido, que o autor realiza uma operação fragmentadora do continente, baseada no conceito de progresso e civilização e nos seus fundamentos explicativos de caráter racialista, destacava a Argentina, o Chile e o Brasil de uma imagem da América Latina unificada sob atributos negativos.

Por sua vez, Joaquim Nabuco, apesar da necessária ponderação ao analisar os seus discursos - frutos da sua ocupação de um cargo oficial na política brasileira - deixou evidente que no interior do pan-americanismo, o único país com o qual tínhamos que nos aproximar era com os Estados Unidos. A América Latina, ainda não tinha entrado no palco da civilização e ao Brasil, portanto, era imprescindível diferenciar-se do restante do continente através da incorporação dos elementos brancos advindos com a imigração européia, tal qual o exemplo que Nabuco tanto admirava da grande república do norte. Nessa direção, a insistência do embaixador brasileiro em Washington ao manter uma política de alianças somente entre os dois países revelava também a sua visão hierárquica do continente ao considerar a civilização norte-americana superior a da América Latina. O pan-americanismo pensado por Nabuco colocava os Estados Unidos como o líder do continente, cabendo ao Brasil o papel de interlocutor privilegiado entre esse país e os demais países do subcontinente. Para garantir tal papel, era imprescindível que o país recebesse imigrantes europeus, ultrapassasse a Argentina na quantificação de sua 
população branca e mostrasse-se ao mundo como uma nação embranquecida com a possibilidade de alcançar um nível elevado de progresso e civilização.

Podemos nesse sentido, perceber a face de um tipo de Pan-americanismo pensado por Oliveira Lima que, apesar de propor a união entre as repúblicas "excepcionais" da América Latina o faz com base nos atributos civilizacionais e da composição étnica desses países. Apesar de propor uma aliança no interior do pan-americanismo entre as três repúblicas latinas, o modelo a ser alcançado ainda continuava a ser o da América saxônica, com o seu nível civilizacional e seu povo predominantemente branco.

Nesse sentido, buscamos demonstrar que a discussão em torno do Panamericanismo era envolvida diretamente com a discussão racial do período. Ou seja, para além do discurso de que uma aproximação com os Estados Unidos seria uma via de superação do atraso, através de uma aproximação com os valores e instituições norte-americanas, a aproximação com os Estados Unidos ou com a América Latina passava, para alguns desses intelectuais brasileiros, pela questão racial. Integrar-se aos Estados Unidos significaria representar-se como um país com possibilidade de alcançar um patamar civilizacional; enquanto a integração com a América Latina significaria persistir na imagem de um país mestiço e, por conseguinte, fadado ao atraso. A questão civilizacional interferiu nas interpretações de aproximação ou de distanciamento desses intelectuais com os Estados Unidos ou com a América Latina no início da República $^{26}$. São essas questões, que, incluindo todo um arcabouço de um discurso racial - muitas vezes um discurso velado - freqüentemente contraditórias nas suas próprias proposições, é que nos instigaram a adentrar mais a fundo no embate travado por estes pensadores nos primórdios da República em torno do Pan-americanismo.

\footnotetext{
${ }^{26}$ Roberto Ventura observou que, até a década de 30, a maioria das obras foram orientadas pelas noções de raça e natureza: "A defasagem política e econômica entre a América do Norte e a sua contraparte latina levou ao recurso a causas geográficas e raciais, para dar conta do 'atraso' do Brasil ou da América do Sul, o que prolongou a disputa do Novo Mundo na crítica literária brasileira do século. [...] Introduziu-se, na literatura e na crítica brasileira, uma visão exótica ou um olhar de fora, que trouxe uma imagem negativa da sociedade e da cultura local, expressa na oscilação entre ufanismo e cosmopolitismo, na tensão entre a ideologia civilizatória e o projeto nacionalista" (Ventura, 1992, p. 41).
} 


\section{Considerações Finais}

Neste artigo, buscamos evidenciar que semelhante ao Brasil, a América Latina, no final do século XIX e início do $X X$, viveu um momento de intenso debate intelectual, com temáticas similares, em que se discutiram questões pertinentes a um período marcado pela intensificação do processo de modernização, bem como os projetos para a superação do atraso e para a elevação dos níveis do progresso e da civilização nesses países.

No Brasil, as questões internacionais viriam coincidir com uma época de grandes transformações. Parte de uma geração de intelectuais estava perdendo suas referências pessoais e políticas em meio ao desmoronamento do mundo construído durante todo o século XIX, primeiro com o esgotamento da causa abolicionista, depois com a queda da monarquia e todos os outros processos que tomavam lugar no plano mundial, entre eles a perda da centralidade européia, o imperialismo e a ascendência dos Estados Unidos no continente americano. Eduardo Prado, Joaquim Nabuco e Oliveira Lima viveram esse dilema em sua época e se viram pressionados a reverem seus conceitos e reestruturar seus pensamentos diante da realidade cultural e social da qual faziam parte. Tais temas ora ocultavam, ora tornavam explícitos os conflitos e tensões que vivenciavam. Mas, independentemente do quanto se esforçaram para imitar os modelos e estilos europeus admirados, nossos autores sempre estiveram falando e escrevendo, cada qual, sobre o seu tempo presente. Dessa atitude não puderam escapar: mais que isso, permitiram que a força das realidades políticas com as quais estavam envolvidos aparecesse subjacente aos seus trabalhos. Assim, admitir a historicidade dos seus textos torna-se a condição necessária para compreendermos as suas idéias. Nessa direção, Eduardo Prado, conhecido pelo seu europeísmo, relutou em aceitar a república e a "ilusão americana" advinda com o novo regime. Ferrenho defensor monárquico e da cultura européia, suas críticas à política de aproximação com as Américas podem ser entendidas no binômio "civilização" e "barbárie". Os Estados Unidos seriam considerados pela visão de Prado como uma nova barbárie na ordem da civilização e difusor de um imperialismo cruel na ordem das relações internacionais no continente. 
Nabuco e Oliveira Lima, encontravam, no entanto, nos Estados Unidos, um povo da mesma raiz racial que os ingleses e, por isso, com potencialidades latentes de desenvolvimento de uma civilização na América que estava surpreendendo em vários aspectos. Ao pretendermos buscar o início da identificação ou afastamento dos dois autores com os países americanos percebemos que, ao definirem a necessidade de uma aproximação estreita com os Estados Unidos, assumiam argumentos, não só em termos políticos mas também civilizacionais e raciais. A posição que o Brasil assumia no interior do Pan-americanismo, como aliado mais próximo dos Estados Unidos, proporcionava uma identidade e interesse comum de desenvolvimento, proteção e uma espécie de "aliança" com o país mais "evoluído" no sistema americano.

\section{Bibliografia}

ABRANCHES, Dunshee de. 1945. Rio Branco e a política exterior do Brasil (1902-1912). In Obras Completas. Vol. II. Rio de Janeiro: Jornal do Brasil, 1945.

ALONSO, Angela. 2009. Arrivistas e decadentes. O debate político-intelectual brasileiro na primeira década republicana. São Paulo: Novos Estudos CEBRAP, № 85, novembro, 2009.

AUERBACH, E. 2007. Ensaios de literatura ocidental. São Paulo: Editora 34, 2007.

BAGGIO, Kátia Gerab. 1999. A "outra" América: a América Latina na visão dos intelectuais brasileiros das primeiras décadas republicanas. São Paulo: Departamento de História da USP: 1999. [Tese de Doutorado, mimeo].

BARBOSA, Rui. 1998. Obras seletas de Rui Barbosa. Vol. VIII. Campanhas jornalísticas. República 1899-1918. 3o volume. Rio de Janeiro: Record, 1998.

BRANDÃO, Gildo Marçal. 2007. Linhagens do pensamento político brasileiro. São Paulo: Editora Hucitec, 2007.

CANDIDO, Antonio. 1993. "Os brasileiros e a nossa América". In Recortes. São Paulo: Companhia das Letras, 1993.

CUNHA, Euclides. 1995. "O ideal americano". In Contrastes e confrontos. In CUNHA, Euclides. Obra completa. Vol. I. Rio de Janeiro: Editora Nova Aguilar, 1995.

FREYRE, Gilberto. 2000. Ordem e progresso. In SANTIAGO, Silvano (org.). Intérpretes do Brasil, Vol. III. Rio de Janeiro: Nova Aguilar, 2000.

GRAHAM, Richard. 1973. Grã-Bretanha e o início da modernização no Brasil: 1850-1914. São Paulo: Brasiliense, 1973.

JANOTTI, Maria de Lourdes Mônaco. 1986. Os subversivos da República. São Paulo: Brasiliense, 1986.

LINS, Álvaro. 1965. Rio Branco. 2ª Ed. São Paulo: Companhia Editora Nacional, 1965.

MAGNOLI, Demétrio. 1997. O corpo da pátria: imaginação geográfica e política externa no Brasil. São Paulo: UNESP; Moderna, 1997.

MALATIAN, Teresa. 2001. Oliveira Lima e a construção da nacionalidade. Bauru: EDUSC; São Paulo: FAPESP, 2001. 
MANNHEIM, Karl. 1986. "O pensamento conservador". In MARTINS, José de Souza. Introdução crítica à sociologia rural. São Paulo: Hucitec, 1986.

NABUCO, Joaquim. 1895. Balmaceda. Rio de Janeiro: Typographia Leuzinger, 1895.

. 1990a. A intervenção estrangeira durante a Revolta da Armada. In DANTAS, Leonardo (org.). Joaquim Nabuco e a República. Vol. 6. Recife: Massangana-Fundação Joaquim Nabuco, 1990.

. 1990b. "O dever dos monarquistas". In DANTAS, Leonardo (org.). Joaquim Nabuco e a República. Vol. 6. Recife: Massangana-Fundação Joaquim Nabuco, 1990. . 1997. Um estadista do Império. $5^{\text {a }}$ ed. Rio de Janeiro: Topbooks, 1997. 2 vols. 1963. Minha formação. Brasília: Editora da Universidade de Brasília, 1963. . 2000. O abolicionismo. Rio de Janeiro: Nova Fronteira; São Paulo: Publifolha, 2000.

OLIVEIRA LIMA, Manoel. 1899. Nos Estados Unidos: impressões políticas e sociais. Leipzig: F. A Brockhaus, 1899.

PEREIRA, Paulo dos Reis. 2006. A política externa da Primeira República e os Estados Unidos: a atuação de Joaquim Nabuco em Washington (1905-1910). São Paulo: Hucitec; FAPESP, 2006.

PRADO, Eduardo. 1957. A ilusão americana. São Paulo: Brasiliense, 1957. . 1959. Trechos Escolhidos. Mário Casasanta (org.). Col. Nossos Clássicos, 39. Rio de Janeiro: Agir, 1959.

QUEIROZ, Suely Robles Reis de. 1986. Os radicais da República. Jacobinismo: ideologia e ação 1893-1897. São Paulo: Brasiliense, 1986.

SILVEIRA, Helder Gordim da. 2003. Joaquim Nabuco e Oliveira Lima: faces de um paradigma ideológico da americanização nas relações internacionais do Brasil. Porto Alegre: EDIPUCRS, 2003.

SKIDMORE, Thomas E. 1994. "Eduardo Prado: um crítico nacionalista conservador da Primeira República Brasileira, 1889-1901". In O Brasil visto de fora. Rio de Janeiro: Paz e Terra, 1994.

VENTURA, Roberto. 1992. Estilo tropical: história cultural e polêmicas literárias no Brasil. São Paulo: Companhia das Letras, 1992.

VOVELLE, Michel. 2000. Jacobinos e jacobinismos. Bauru: EDUSC, 2000.

Submetido em 2011-07-19

Aceito em 2011-10-26 